\title{
50. TRACE ELEMENT CONTENTS OF CARBONATES FROM HOLES 549 AND 550B (LEG 80): COMPARISON WITH SOME TETHYAN AND ATLANTIC SITES1
}

\author{
Annick Andrianiazy and Maurice Renard, Département de Géologie Sédimentaire, \\ Université Pierre et Marie Curie $^{2}$
}

\begin{abstract}
The evolution through time of trace element contents $(\mathrm{Sr}, \mathrm{Mg}, \mathrm{Mn}$, and $\mathrm{Fe})$ of sediments at Sites 549 and 550 is similar to that of previously studied oceanic sites. A comparison with some North Atlantic sites and with outcrops of the Gubbio section (Italy) allowed us to show that

1. A negative correlation between $\mathrm{Sr}$ and $\mathrm{Mg}$ contents, generally characteristic of pelagic carbonate having undergone diagenesis, is confirmed.

2. Magnesium diagenesis occurs over a relatively short time and is sensitive to the sedimentation rate of each individual time period, whereas $\mathrm{Sr}$ diagenesis is a long-term phenomenon and is sensitive to the overall average sedimentation rate at the site. Strontium loss by sediments is related to sediment age (i.e., residence time of sediments in a given diagenetic environment) and could be a rough method of dating individual sediment layers.

3. The nature of the seafloor (oceanic or continental) does not appear to play an important part in the content of Fe and $\mathrm{Mn}$ in sediments. Their distribution depends more on mid-oceanic ridge activity, paleodepth (through mediation of $\mathrm{CaCO}_{3}$ dissolution and environment), and distance of the site from the ridge.
\end{abstract}

\section{INTRODUCTION}

Previous studies of sediments from Holes 390,391 , 392, 398C, 400A, 516F, and 116 (Renard et al., 1978, 1979,1982 ) have shown the potential use of $\mathrm{Sr}$ as a time marker for pelagic carbonate diagenesis (because of $\mathrm{Sr}$ loss with time). Also, the manganese-iron couple appears to be an indicator of submarine volcano-hydrothermal activity. Moreover, the study of pelagic facies from continental outcrops, such as from the Gubbio section of Umbria, Italy, has shown a negative $\mathrm{Sr} / \mathrm{Mg}$ correlation characteristic of the diagenesis of pelagic carbonates, whereas this correlation is positive for diagenesis of continental shelf carbonates. Because of the high $\mathrm{Mg}$ concentration of interstitial waters, the relationship between $\mathrm{Sr}$ and $\mathrm{Mg}$ in sediments has rarely been studied at DSDP sites.

The aim of the present work is therefore (1) to test the generality of the negative $\mathrm{Sr} / \mathrm{Mg}$ relationship in oceanic carbonates (for this purpose, the sediments were washed to eliminate $\mathrm{Mg}$ from their interstitial waters), and (2) to compare the geochemistry of $\mathrm{Fe}$ and $\mathrm{Mn}$ in carbonates on continental crust (Site 549) with those on oceanic crust (Site 550).

\section{METHODS}

The geochemistry of trace elements was studied on 141 samples from Hole 549 ranging in age from Pleistocene to Barremian and on 45 samples from Hole 550B ranging in age from early Paleocene to late Albian.

After being crushed, the samples were washed to eliminate interstitial water. The washes consisted of multiple (an average of 12) centri-

\footnotetext{
${ }^{1}$ Graciansky, P. C. de, Poag, C. W., et al., Init. Repts. DSDP, 80: Washington (U.S. Govt, Printing Office).

2 Addresses: (Andrianiazy) Département de Géologie Sédimentaire, Université Pierre et Marie Curie (Paris VI) et Bureau Recherche Géologique et Minière Orléans; (Renard) Département de Géologie Sédimentaire, Université Pierre et Marie Curie (Paris VI) et Laboratoire Associé au Centre National de la Recherche Scientifique 319.
}

fugations with distilled water. The conductivity of the wash water was measured after each centrifugation, and the treatment was stopped when the conductivity of the wash water stopped decreasing and reached a plateau. X-ray diffraction of the carbonate samples showed mainly the presence of low-Mg calcite. Some samples containing dolomite were eliminated from the study. After this pretreatment, samples were dissolved in $1 \mathrm{~N}$ acetic acid. Trace element analysis was conducted by atomic absorption spectrometry using the methods described by Renard and Blanc $(1971,1972)$. The data are summarized in Table 1.

\section{RESULTS}

\section{Strontium}

Sr contents in carbonates from Hole 549 range from $1400-1500 \mathrm{ppm}$ for Miocene-Oligocene aged sediments to $400 \mathrm{ppm}$ for Cenomanian sediments (Fig. 1). This decrease with age is caused by increasing diagenesis with depth. It should be noted that the loss of Sr is not regular. Sediments deposited during certain periods, such as Eocene and mid-Cretaceous, are impoverished in $\mathrm{Sr}$, whereas others deposited during Albian, late Paleocene, and late Oligocene time are enriched in comparison to the average curve. These divergences could have a stratigraphic significance (Renard et al., 1982). Similarly for Hole 550B, a decrease with age in $\mathrm{Sr}$ can be observed: from $1200 \mathrm{ppm}$ in lower Paleocene sediments to 500 ppm in Santonian-Coniacian sediments (Fig. 1). Sr-rich (Albian-Cenomanian) and Sr-poor periods (middle-Late Cretaceous) also exist in this hole.

The variations of average $\mathrm{Sr}$ concentrations in interstitial waters at Site 549 (Gieskes, this volume) are plotted in Figure 2. For at least up through Eocene time, this plot is the inverse of the plot of $\mathrm{Sr}$ concentration in sediments (Fig. 2), thus helping to confirm the influence of recrystallization in $\mathrm{Sr}$ distribution.

That the variation in $\mathrm{Sr}$ concentrations in interstitial waters is related to sedimentation rate has been clearly shown by Manheim et al. (1971; Leg 8$)$ and by Gieskes 
Table 1 . Summary of results-Holes 549, 549A, 550B.

\begin{tabular}{|c|c|c|c|c|c|}
\hline $\begin{array}{l}\text { Core-Section } \\
\text { (interval in } \mathrm{cm} \text { ) }\end{array}$ & $\begin{array}{c}\mathrm{CaCO}_{3} \\
(\%)\end{array}$ & $\begin{array}{c}\mathrm{Mg} \\
(\mathrm{ppm})\end{array}$ & $\begin{array}{c}\mathrm{Sr} \\
(\mathrm{ppm})\end{array}$ & $\begin{array}{c}\mathrm{Mn} \\
\text { (ppm) }\end{array}$ & $\begin{array}{c}\mathrm{Fe} \\
\text { (ppm) }\end{array}$ \\
\hline \multicolumn{6}{|l|}{ Hole 549} \\
\hline $1-5,58-60$ & 75.94 & 1666 & 1140 & 775 & 130 \\
\hline $2-1,38-40$ & 79.71 & 1492 & 1220 & 829 & 263 \\
\hline $3-1,4-6$ & 79.47 & 1554 & 1111 & 798 & 183 \\
\hline $4-1,105-107$ & 65.31 & 1447 & 1457 & 716 & 170 \\
\hline $4-5,105-107$ & 74.56 & 1648 & 1160 & 1055 & 240 \\
\hline $5-1,54-55$ & 77.83 & 1632 & 1126 & 1061 & 335 \\
\hline $5-3,54-55$ & 73.16 & 1658 & 1121 & 1102 & 270 \\
\hline $6-1,68-69$ & 71.53 & 1669 & 1168 & 1052 & 112 \\
\hline $6-5,68-69$ & 65.55 & 1920 & 1186 & 1027 & 60 \\
\hline $7-1,37-39$ & 66.02 & 1877 & 1181 & 1085 & 84 \\
\hline $7-5,67-69$ & 68.84 & 1774 & 1113 & 936 & 124 \\
\hline $8-1,79-80$ & 74.27 & 1741 & 1020 & 939 & 100 \\
\hline $8-3,79-80$ & 76.28 & 1609 & 1065 & 885 & 94 \\
\hline $9-1,44-45$ & 74.88 & 1617 & 1060 & 1124 & 142 \\
\hline $9-3,29-30$ & 74.40 & 1575 & 1046 & 1163 & 124 \\
\hline $10-1,77-78$ & 76.28 & 1690 & 1073 & 898 & 20 \\
\hline $10-3,81-83$ & 58.84 & 1346 & 1090 & 1188 & 17 \\
\hline $10-5,60-62$ & 78.51 & 1475 & 1069 & 902 & 15 \\
\hline $11-1,106-108$ & 66.92 & 1913 & 1275 & 3827 & 28 \\
\hline $11-5,115-117$ & 46.84 & 2280 & 1295 & 3160 & 65 \\
\hline $12-1,60-62$ & 52.19 & 1761 & 1206 & 3177 & 55 \\
\hline $12-3,54-56$ & 45.59 & 2437 & 1210 & 3046 & 62 \\
\hline $13-1,63-65$ & 71.81 & 1430 & 953 & 2780 & 70 \\
\hline $13-5,64-66$ & 79.80 & 1457 & 806 & 1953 & 78 \\
\hline $14-1,64-66$ & 78.33 & 1447 & 831 & 1220 & 76 \\
\hline $14-5,22-24$ & 69.25 & 1808 & 996 & 2924 & 199 \\
\hline $15-1,61-62$ & 50.56 & 2095 & 1017 & 2352 & 221 \\
\hline $15-3,60-62$ & 38.97 & 3184 & 1180 & 2077 & 152 \\
\hline $15-5,61-63$ & 49.57 & 2800 & 1074 & 2262 & 225 \\
\hline $16-1,62-63$ & 51.34 & 2739 & 1054 & 2702 & 316 \\
\hline $16-3,58-59$ & 57.23 & 2179 & 963 & 2996 & 391 \\
\hline $16-5,64-65$ & 42.89 & 4300 & 996 & 1766 & 110 \\
\hline $17-1,69-70$ & 63.35 & 1580 & 1051 & 1880 & 8 \\
\hline $17-5,71-72$ & 52.19 & 1779 & 1089 & 1810 & 8 \\
\hline $18-1,68-69$ & 61.12 & 1961 & 1198 & 1684 & 11 \\
\hline $18-3,46-47$ & 45.76 & 2297 & 1140 & 1716 & 11 \\
\hline $19-1,19-20$ & 47.78 & 2845 & 1057 & 2269 & 8 \\
\hline $19-3,34-35$ & 74.92 & 1662 & 972 & 2302 & 12 \\
\hline $20-1,24-25$ & 63.80 & 1644 & 1164 & 2376 & 26 \\
\hline $20-3,20-21$ & 68.48 & 1496 & 1145 & 2914 & 54 \\
\hline $20-5,13-14$ & 75.27 & 1182 & 1074 & 2372 & 50 \\
\hline $21-2,2-3$ & 76.54 & 1090 & 1107 & 1849 & 41 \\
\hline $22-2,109-110$ & 93.48 & 1056 & 819 & 439 & 15 \\
\hline $22-4,93-94$ & 93.92 & 1045 & 800 & 677 & 18 \\
\hline $23-2,65-67$ & 92.31 & 934 & 800 & 390 & 11 \\
\hline $23-4,54-56$ & 94.89 & 886 & 746 & 282 & 12 \\
\hline $24-2,28-30$ & 91.43 & 928 & 678 & 911 & 17 \\
\hline $25-2,37-39$ & 81.91 & 1185 & 615 & 654 & 25 \\
\hline $26-1,7-9$ & 88.98 & 1456 & 455 & 922 & 145 \\
\hline $27-1,0-3$ & 52.02 & 1018 & 692 & 987 & 525 \\
\hline $28-2,28-30$ & 75.32 & 2157 & 472 & 570 & 247 \\
\hline $29-1,34-37$ & 73.35 & 2311 & 373 & 635 & 239 \\
\hline $32-1,27-29$ & 22.51 & 7940 & 714 & 1666 & 1652 \\
\hline $34-1,53-54$ & 41.67 & 5606 & 404 & 1143 & 4268 \\
\hline $34-1,70-73$ & 29.31 & 5879 & 680 & 1168 & 2436 \\
\hline $35-1,44-46$ & 28.59 & 7735 & 753 & 1692 & 1867 \\
\hline $36-1,17-18$ & 40.58 & 6590 & 397 & 778 & 4487 \\
\hline $37-1,21-22$ & 25.34 & 6664 & 954 & 1087 & 1261 \\
\hline $37-2,34-36$ & 32.80 & 6522 & 753 & 1879 & 1944 \\
\hline $40-1,17-20$ & 28.42 & 5265 & 705 & 723 & 93 \\
\hline $42-1,64-66$ & 32.63 & 4981 & 676 & 1682 & 2148 \\
\hline $42-3,85-86$ & 34.01 & 6941 & 829 & 1876 & 1531 \\
\hline $43-2,90-93$ & 32.74 & 7647 & 835 & 2095 & 1200 \\
\hline $43-4,53-54$ & 29.86 & 7065 & 775 & 1981 & 1252 \\
\hline $44-2,2-4$ & 33.12 & 6781 & 603 & 1372 & 1616 \\
\hline $44-4,2-4$ & 31.00 & 6481 & 594 & 1593 & 2295 \\
\hline $45-2,61-63$ & 29.45 & 6956 & 673 & 1797 & 1693 \\
\hline
\end{tabular}

Table 1. (Continued).

\begin{tabular}{lrrrrr}
\hline $\begin{array}{c}\text { Core-Section } \\
\text { (interval in cm) }\end{array}$ & $\begin{array}{c}\mathrm{CaCO}_{3} \\
(\%)\end{array}$ & $\begin{array}{c}\mathrm{Mg} \\
\text { (ppm) }\end{array}$ & $\begin{array}{c}\mathrm{Sr} \\
\text { (ppm) }\end{array}$ & $\begin{array}{c}\mathrm{Mn} \\
\text { (ppm) }\end{array}$ & $\begin{array}{c}\mathrm{Fe} \\
\text { (ppm) }\end{array}$ \\
\hline Hole 549 (Cont.) & & & & & \\
& & & & & \\
$45-4,34-35$ & 30.00 & 6730 & 604 & 1743 & 1390 \\
$46-2,96-99$ & 28.37 & 6260 & 698 & 1762 & 1642 \\
$46-4,93-94$ & 40.89 & 4969 & 657 & 1834 & 2804 \\
$47-2,90-91$ & 39.32 & 5313 & 612 & 753 & 1297 \\
$47-4,20-21$ & 44.65 & 4877 & 617 & 1238 & 2129 \\
$54-4,0-2$ & 42.26 & 9248 & 451 & 591 & 5052 \\
$55-4,124-126$ & 63.73 & 3948 & 321 & 521 & 4369 \\
$56-2,53-55$ & 49.60 & 7085 & 483 & 561 & 6384 \\
$56-4,43-46$ & 29.46 & 11012 & 550 & 565 & 6718 \\
$57-2,62-64$ & 19.34 & 18293 & 637 & 599 & 10199 \\
$57-4,121-123$ & 35.73 & 7552 & 430 & 503 & 10824 \\
$58-2,56-57$ & 23.48 & 9890 & 545 & 580 & 8779 \\
$58-6,79-80$ & 43.28 & 7325 & 508 & 611 & 7503 \\
$59-2,40-42$ & 27.94 & 12223 & 588 & 722 & 7916 \\
$60-2,27-29$ & 42.68 & 7663 & 453 & 675 & 9625 \\
$60-6,70-72$ & 29.91 & 7156 & 532 & 100 & 7156 \\
$61-2,56-58$ & 11.99 & 12340 & 965 & 559 & 4486 \\
$61-4,116-118$ & 17.72 & 7660 & 740 & 799 & 5453 \\
$74-2,21-23$ & 14.22 & 11419 & 589 & 1035 & 13516 \\
$75-2,57-59$ & 67.20 & 5600 & 550 & 597 & 8670 \\
$79-1,32-34$ & 39.50 & 6061 & 288 & 1212 & 8323 \\
$80-1,51-53$ & 49.23 & 4577 & 552 & 2284 & 6567 \\
$99-1,145-146$ & 58.94 & 11865 & 297 & 9875 & 15193 \\
& & & & &
\end{tabular}

Hole 549A

4-3, 105-109

$5-2,32-36$

$6-2,44-48$

$7-3,73-78$

$8-3,16-20$

$9-2,114-118$

$11-3,74-78$

$12-1,96-100$

$13-1,90-94$

$13-3,116-120$

$15-1,60-64$

$16-1,76-80$

$17-1,53-57$

$19-1,28-32$

$21-1,34-38$

24-2, 66-70

$25-2,82-86$

26-1, 48-52

28-1, 111-115

$33-2,46-50$

$34-1,62-65$

36-1, 10-15

$37-1,4-9$

38-1, 36-39

$42-1,30-33$
$10-4,74-78$

$14-1,86-90$

$15-2,64-68$

$17-2,14-18$

18-1, 76-80

20-1, 48-52

$24-1,57-60$

27-1, 93-97

$32-2,22-25$

35-1, 16-19

$39-2,22-25$

40-1, 53-56

41-1, 13-16

$\begin{array}{lrr}82.38 & 1429 & 1394 \\ 84.43 & 1190 & 1445 \\ 80.30 & 1339 & 1542 \\ 88.74 & 1150 & 1353 \\ 87.91 & 1135 & 1311 \\ 87.36 & 1116 & 1438 \\ 85.88 & 968 & 1543 \\ 83.25 & 1477 & 1298 \\ 85.41 & 1329 & 1351 \\ 84.91 & 1164 & 1412 \\ 87.39 & 1043 & 1398 \\ 83.40 & 970 & 1520 \\ 83.18 & 1207 & 1450 \\ 86.22 & 1008 & 1471 \\ 87.22 & 995 & 1464 \\ 85.84 & 1195 & 1453 \\ 86.85 & 1041 & 1513 \\ 91.62 & 1016 & 1291 \\ 90.57 & 973 & 1286 \\ 89.38 & 967 & 1289 \\ 91.83 & 1022 & 1209 \\ 84.04 & 1253 & 1361 \\ 91.72 & 1119 & 1244 \\ 89.33 & 1070 & 1301 \\ 85.67 & 1093 & 1335 \\ 86.56 & 1209 & 1269 \\ 86.54 & 1200 & 1263 \\ 84.25 & 1374 & 1210 \\ 85.17 & 1136 & 1339 \\ 84.43 & 1048 & 1387 \\ 81.29 & 1397 & 1300 \\ 85.12 & 1150 & 1314 \\ 85.12 & 1074 & 1356 \\ 80.77 & 1145 & 1254 \\ 79.47 & 1338 & 1254 \\ 77.85 & 1229 & 1375 \\ 80.21 & 1468 & 1267 \\ 82.39 & 1365 & 1244\end{array}$

$183 \quad 38$

238.29

370

579

$462 \quad 13$

$590 \quad 38$

$549 \quad 37$

$\begin{array}{rr}727 & 5 \\ 717 & 10\end{array}$

$666 \quad 49$

$706 \quad 192$

$622 \quad 175$

$628 \quad 190$

$798 \quad 186$

$661 \quad 162$

$821 \quad 143$

$633 \quad 138$

$600 \quad 156$

$615 \quad 184$

$557 \quad 234$

$676 \quad 182$

$653 \quad 34$

$\begin{array}{ll}795 & 42 \\ 726 & 45\end{array}$

$580 \quad 20$

$877 \quad 24$

$749 \quad 28$

$1019 \quad 20$

$950 \quad 19$

$790 \quad 23$

$750 \quad 21$

$\begin{array}{ll}849 & 36 \\ 795 & 56\end{array}$

$853 \quad 198$

$819 \quad 83$

$841 \quad 156$

$706 \quad 150$

Hole 550B

8

$1-3,9-14$
1417
$791 \quad 1099$ 
Table 1. (Continued).

\begin{tabular}{|c|c|c|c|c|c|}
\hline $\begin{array}{l}\text { Core-Section } \\
\text { (interval in } \mathrm{cm} \text { ) }\end{array}$ & $\underset{(\%)}{\mathrm{CaCO}_{3}}$ & $\underset{(\mathrm{ppm})}{\mathrm{Mg}}$ & $\begin{array}{c}\mathrm{Sr} \\
(\mathrm{ppm})\end{array}$ & $\underset{(\mathrm{ppm})}{\mathrm{Mn}}$ & $\begin{array}{c}\mathrm{Fe} \\
(\mathrm{ppm})\end{array}$ \\
\hline \multicolumn{6}{|c|}{ Hole 550B (Cont.) } \\
\hline $1-3,63-66$ & 62.76 & 948 & 1120 & 2252 & 682 \\
\hline $2-2,33-36$ & 58.57 & 1283 & 762 & 1585 & 13 \\
\hline $2-2,37-40$ & 89.32 & 1487 & 848 & 1143 & 17 \\
\hline $3-1,109-114$ & 82.74 & 706 & 917 & 840 & 7 \\
\hline $4-1,57-60$ & 75.87 & 658 & 1035 & 1262 & 12 \\
\hline $5-2,70-73$ & 85.73 & 619 & 856 & 1424 & 23 \\
\hline $5-2,127-131$ & 89.13 & 708 & 819 & 1102 & 33 \\
\hline $5-4,28-31$ & 85.82 & 663 & 982 & 1514 & 45 \\
\hline $5-4,140-143$ & 93.37 & 876 & 853 & 1425 & 46 \\
\hline $7-1,60-63$ & 49.03 & 1139 & 1205 & 722 & 39 \\
\hline $8-1,41-44$ & 92.92 & 1553 & 695 & 1473 & 217 \\
\hline $8-1,114-117$ & 92.90 & 2090 & 514 & 1640 & 393 \\
\hline $8-3,76-79$ & 89.71 & 982 & 812 & 1120 & 230 \\
\hline $9-1,110-113$ & 80.55 & 1092 & 862 & 3392 & 871 \\
\hline $9-4,52-56$ & 58.75 & 811 & 1229 & 1651 & 519 \\
\hline $9-4,96-99$ & 91.00 & 654 & 954 & 2123 & 598 \\
\hline $10-1,61-64$ & 51.76 & 1088 & 1152 & 1420 & 476 \\
\hline $10-3,114-117$ & 62.15 & 776 & 1210 & 1670 & 477 \\
\hline $10-5,40-44$ & 51.23 & 1044 & 1311 & 1608 & 359 \\
\hline $11-1,96-100$ & 87.08 & 877 & 881 & 1355 & 304 \\
\hline $11-3,80-83$ & 37.95 & 2388 & 1271 & 1741 & 229 \\
\hline $12-2,42-45$ & 92.45 & 1553 & 687 & 2055 & 268 \\
\hline $12-4,90-93$ & 75.84 & 843 & 839 & 1726 & 59 \\
\hline $13-1,40-43$ & 94.12 & 1162 & 634 & 2483 & 134 \\
\hline $13-1,89-93$ & 91.30 & 1229 & 449 & 2616 & 380 \\
\hline $13-2,76-79$ & 73.99 & 862 & 704 & 1896 & 38 \\
\hline $15-5,73-79$ & 80.26 & 862 & 753 & 3293 & 654 \\
\hline $16-2,87-91$ & 74.63 & 927 & 747 & 4522 & 973 \\
\hline $17-1,120-124$ & 73.83 & 865 & 790 & 3972 & 1032 \\
\hline $17-2,125-128$ & 72.33 & 887 & 850 & 3316 & 891 \\
\hline $17-5,63-70$ & 75.39 & 831 & 760 & 3760 & 927 \\
\hline $18-7,66-69$ & 73.53 & 973 & 804 & 3151 & 767 \\
\hline $20-2,113-118$ & 57.78 & 1371 & 914 & 2362 & 449 \\
\hline $20-4,17-20$ & 74.00 & 1520 & 596 & 2534 & 788 \\
\hline $21-2,41-44$ & 48.93 & 1548 & 952 & 1040 & 487 \\
\hline $21-5,25-28$ & 64.04 & 1133 & 858 & 2010 & 1513 \\
\hline $22-1,74-77$ & 58.98 & 1459 & 899 & 2225 & 1809 \\
\hline $22-3,119-122$ & 59.63 & 1286 & 838 & 1624 & 1529 \\
\hline $22-5,54-57$ & 68.33 & 1566 & 746 & 2722 & 2051 \\
\hline $23-1,18-21$ & 61.87 & 1378 & 779 & 2122 & 1780 \\
\hline $23-3,96-99$ & 64.50 & 1306 & 683 & 2388 & 1918 \\
\hline $24-2,60-63$ & 51.14 & 1558 & 798 & 1854 & 1239 \\
\hline $25-1,47-50$ & 66.94 & 2054 & 672 & 2248 & 1987 \\
\hline
\end{tabular}

(1976; Leg 33). Sites having the highest sedimentation rates also have the highest variations in interstitial water composition.

The relationship between the rate of sedimentation and the chemistry of the carbonates appears to be more complex. In Hole 549 the average $\mathrm{Sr}$ concentration for any given sediment interval has no direct relationship to the corresponding sedimentation rate. An inverse correlation exists, however, between the cumulative sedimentation rate (Fig. 3) and the $\mathrm{Sr}$ concentration, at least for the Paleocene-Miocene time interval. This negative correlation does not hold for the Cretaceous sediments. This means that either the diagenetic process or the chemistry of the ocean water was different in the Cretaceous. To go further with this analysis, we have made a comparison of these results with those obtained for Hole 400A (Renard, Létolle, et al., 1979). In contrast to Site 549 , this site is characterized by a substantial accumula- tion of post-Oligocene sediments. Consequently, curves of chemical evolution of interstitial waters through time are different for these two sites (Fig. 2). The Sr/Ca ratio for water is about $8 \times 10^{-2}$ at $100 \mathrm{~m}$ depth in Hole $400 \mathrm{~A}$ (Pliocene) and about $1.4 \times 10^{-2}$ at $100 \mathrm{~m}$ depth (Oligocene) in Hole 549. The difference, however, diminishes with depth: the $\mathrm{Sr} / \mathrm{Ca}$ ratio is $3 \times 10^{-2}$ at $500 \mathrm{~m}$ depth (Eocene) for Hole $400 \mathrm{~A}$ and $1 \times 10^{-2}$ for Hole 549 (Cretaceous).

Note the plot of $\mathrm{Sr}$ content versus cumulative sedimentation rate for Holes $400 \mathrm{~A}$ and 549 in Figure 3. The plot of Hole $400 \mathrm{~A}$ varies in a nearly opposite manner from that of Hole 549. This "antithetic" behavior implies that the rate of sedimentation for $\mathrm{Sr}$ is not the main factor controlling diagenesis.

Overall both sites display a similar decrease in $\mathrm{Sr}$ content with increasing age of sediments (Figs. 2 and 3 ). The average values from Hole $400 \mathrm{~A}$, however, are always higher than those from Hole 549, with the difference gradually diminishing with the age of the sediments. Carbonates from Hole 400A show the largest amplitude of variation in the $\mathrm{Sr} / \mathrm{Ca}$ ratio of interstitial waters and the highest $\mathrm{Sr}$ content in sediments, whereas Hole 549 shows the lowest $\mathrm{Sr}$ content in carbonate and also shows less variation in the $\mathrm{Sr} / \mathrm{Ca}$ ratio of interstitial waters. Hole 116 is intermediate between the two, especially for the plots of interstitial waters.

It is thus possible that the rate of sedimentation controls the amplitude of the chemical variations in the interstitial waters. The $\mathrm{Sr} / \mathrm{Ca}$ ratio is close to seawater values for sites with low sedimentation rates but exceeds this ratio for sites with high sedimentation rates. In contrast, the rate of diagenetic transformation of sediments is apparently controlled by their age or, more exactly, the residence time of sediments in a given diagenetic environment.

During dissolution and recrystallization, the newly formed calcite attains equilibrium with its diagenetic environment. Note, however, that the difference in $\mathrm{Sr}$ content of sediments among different sites is only $\sim 20 \%$, whereas the difference in $\mathrm{Sr}$ content of interstitial waters is $\sim 80 \%$. This implies that $K_{\mathrm{Sr}}^{\text {calcite }}$ during the transformation of low- $\mathrm{Mg}$ calcite to low-Mg calcite is considerably less than the equilibrium constant corresponding to inorganic precipitations $\left(K_{\mathrm{Sr}}=0.14\right.$ at $25^{\circ} \mathrm{C}$ [Kinsman, 1969]). The $K_{\mathrm{Sr}}$ value of 0.04 (Katz et al., 1972; Baker et al., 1982) determined from aragonite-calcite transformations seems more appropriate for our use.

\section{Magnesium}

The variation in $\mathrm{Mg}$ content of sediments from Hole 549 are more complex than those of Sr. There is an increase from 1300 to $3250 \mathrm{ppm}$ with increasing depth and age for the late Miocene to late Paleocene interval (Fig. 1). This is inverse to the change in $\mathrm{Sr}$ over the same interval; a similar inverse relationship has been observed at Site 116 and in the Gubbio section outcrop.

A break in the $\mathrm{Mg}$ content curve for upper Paleocene to Maestrichtian sediments is followed by another increasing trend from $1200 \mathrm{ppm}$ in the Maestrichtian section to $6000 \mathrm{ppm}$ in the Albian section. The evolution of 


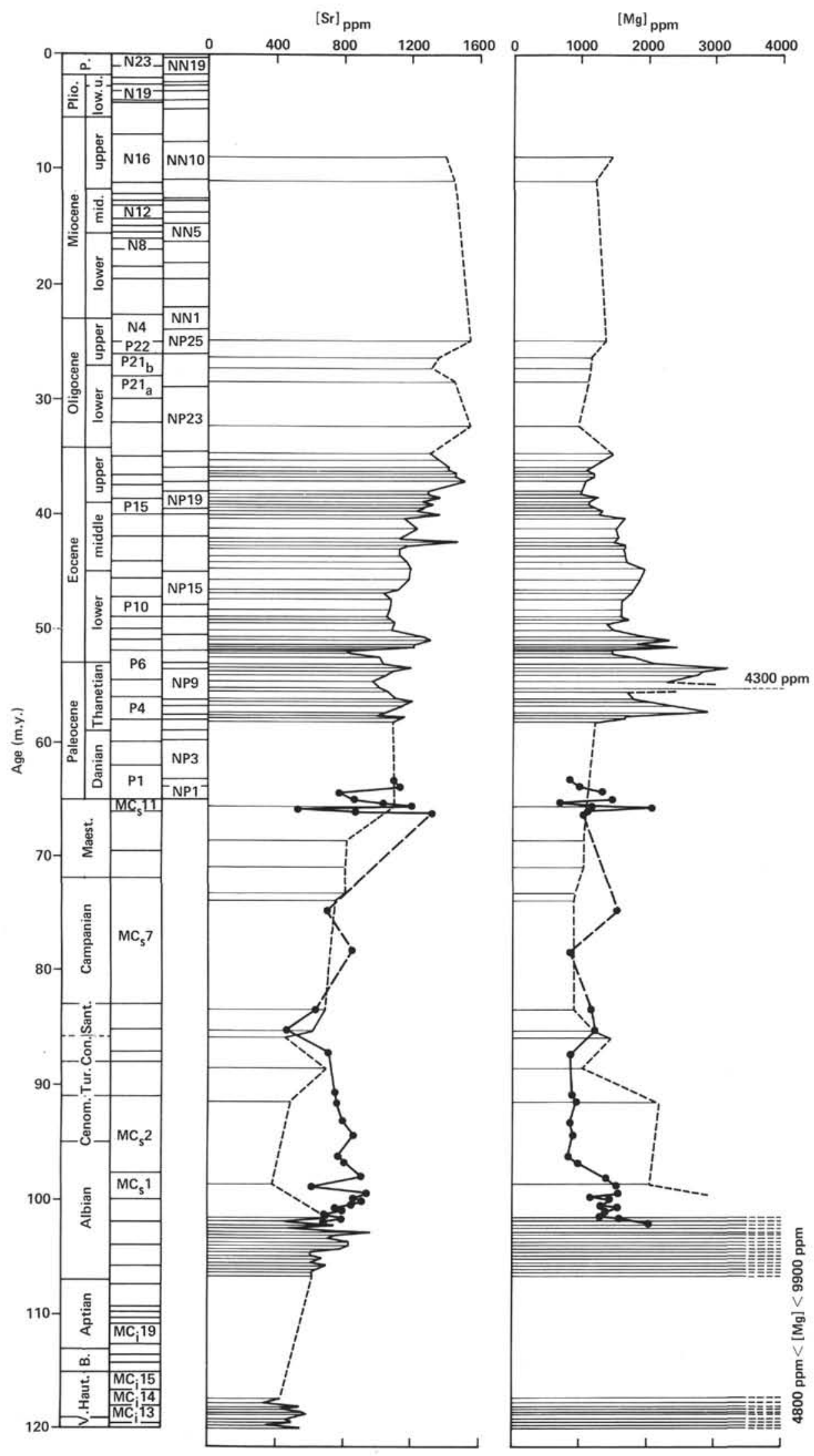

Figure 1. Sr, Mg, Mn, and Fe concentration curves related to sediment age in Holes 549 and 550B. Biostratigraphy is from Snyder et al. (this volume). Absolute age dating is from Odin (1981). Dashed line denotes intervals where profile is uncertain or unknown because of scarcity or absence of data. 

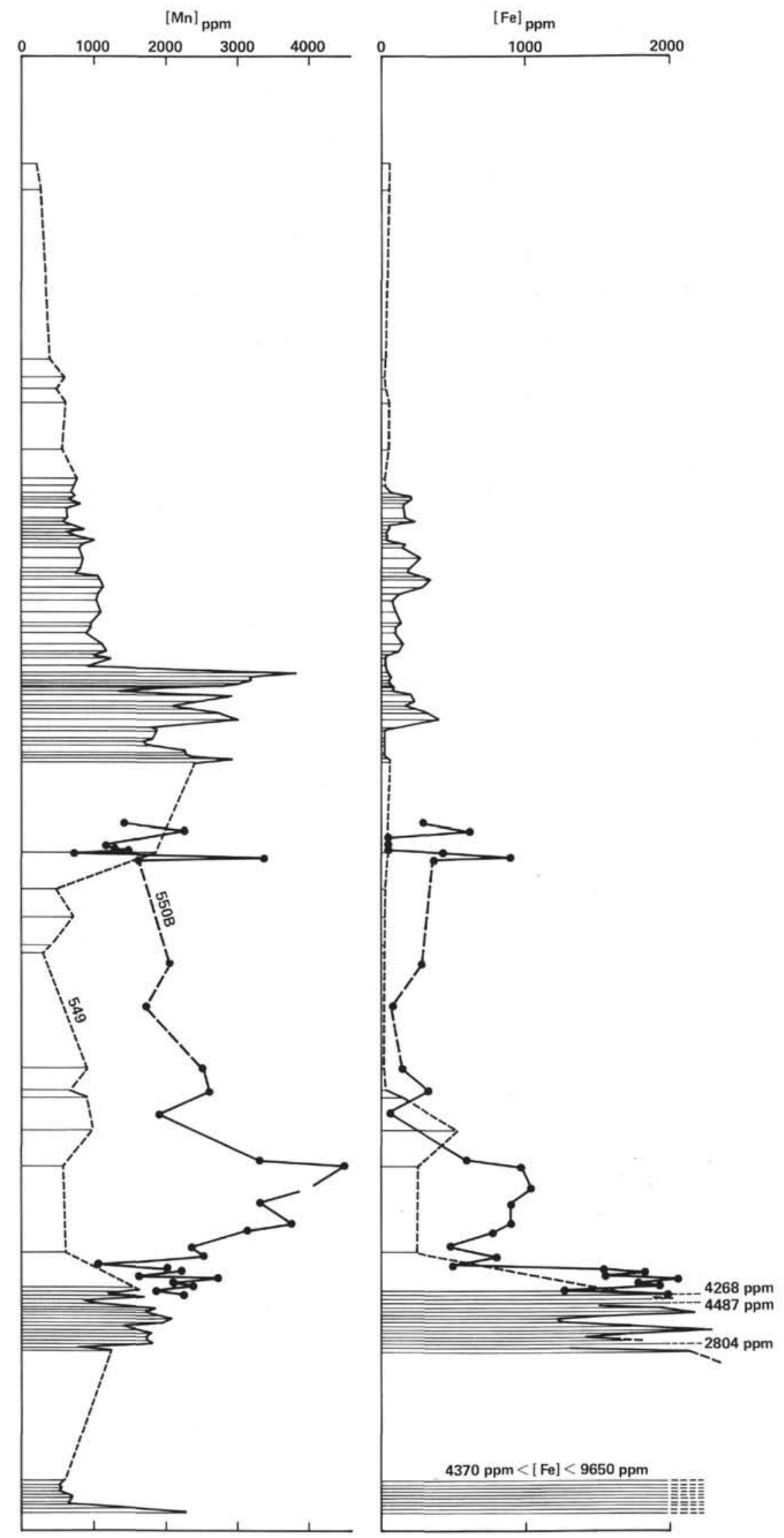

Figure 1. (Continued). 


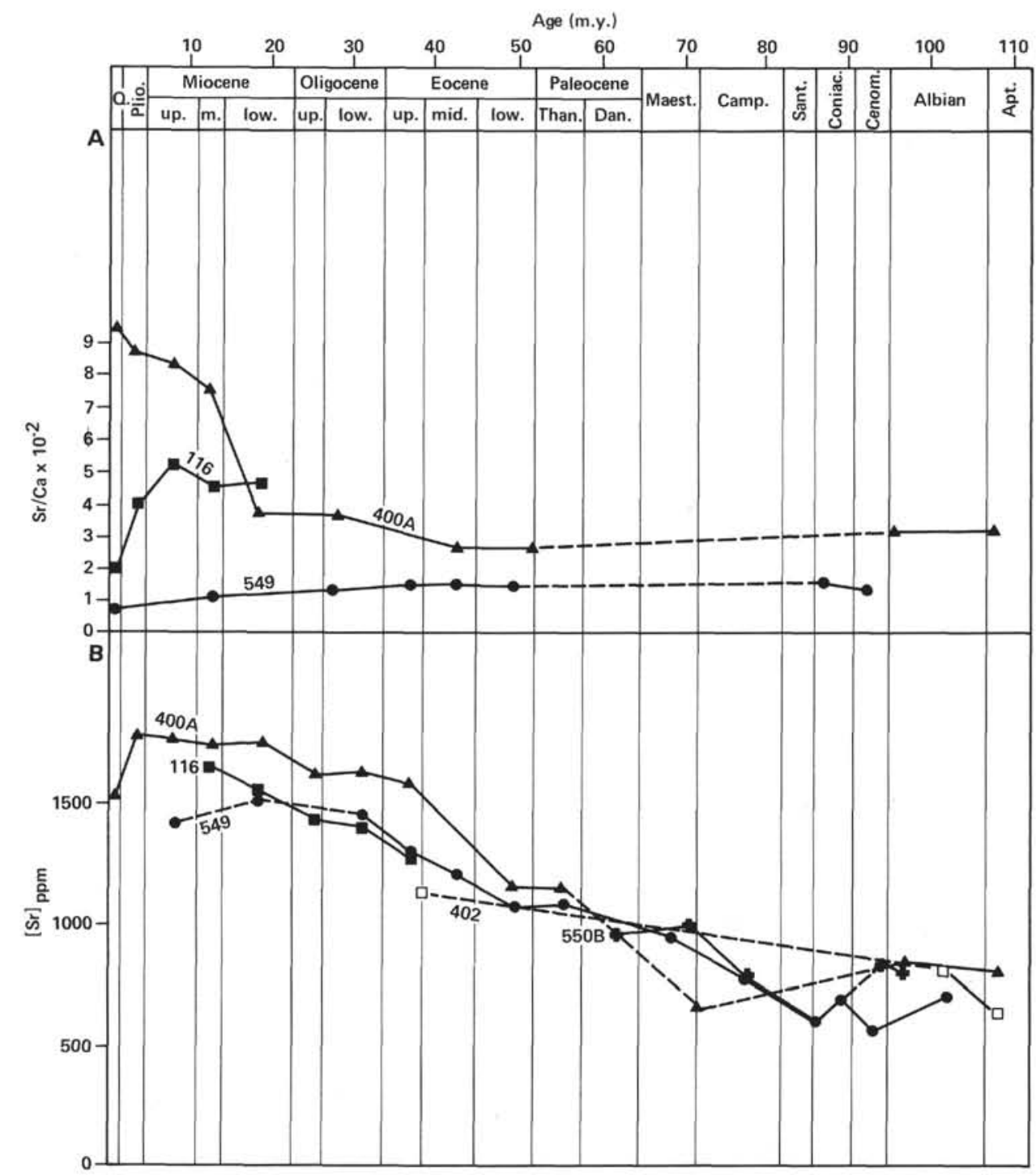

Figure 2. A. Evolution of $\mathrm{Sr} / \mathrm{Ca}$ ratio in interstitial water as related to sediment age for the North Atlantic sites. B. Sr contents of sediments related to age for the same sites. Dashed line as in Fig. 1.

$\mathrm{Mg}$ concentration of the interstitial waters, at least for the post-Paleocene interval, is inversely related to that of the sediments (Gieskes, this volume); $\mathrm{Mg}$ concentrations range from $1300 \mathrm{ppm}$ (Pleistocene) to $1000 \mathrm{ppm}$ (upper Paleocene). The $\mathrm{Mg} / \mathrm{Ca}$ ratio (Fig. 4) for the interstitial waters from Pleistocene to mid-Cretaceous sediments decreases as well. During diagenesis, the newly formed calcite must have been enriched in $\mathrm{Mg}$ at the expense of the interstitial waters. However, the $\mathrm{Mg}$ decrease may not only be caused by carbonate diagenesis but also by the alteration of volcanic materials (Elderfield et al., 1982).

The influence of the sedimentation rate from a given age appears to be more important for $\mathrm{Mg}$ than for $\mathrm{Sr}$ because $\mathrm{Mg}$ shows relatively good positive correlation with the log of the sedimentation rate (Fig. 5). Consequently, the low-Mg content of Upper Cretaceous sediments may be linked to a particularly low sedimentation rate.
The $\mathrm{Mg}$ content of the Upper Cretaceous sediments in Hole 550B is close to that observed in Hole 549 (Fig. 1) and similar to that found in the Gubbio section outcrop (Fig. 4). In contrast, the Tertiary sediments from Gubbio, Hole 549, and Hole 116 have different $\mathrm{Mg}$ concentrations. There are particularly notable differences between the Thanetian values from Gubbio and Hole 549. These differences disappear, at least in the Tertiary sections, if the plot of $\mathrm{Mg}$ concentration versus the apparent rate of sedimentation is considered (Fig. 4). But a difference persists between Site 116 and Site 549 for the Oligocene to Miocene interval. Because of the existence of numerous hiatuses at Sites 549 and 550, which make the calculation of sedimentation rates uncertain, we have not investigated the ratio of $\mathrm{Mg}$ concentration to sedimentation rate for Cretaceous sediments.

Samples from Site 549 show a negative $\mathrm{Sr} / \mathrm{Mg}$ relationship (Fig. 6) characteristic of the diagenesis of pelagic carbonates. It appears that $\mathrm{Mg}$ diagenesis is a rel- 


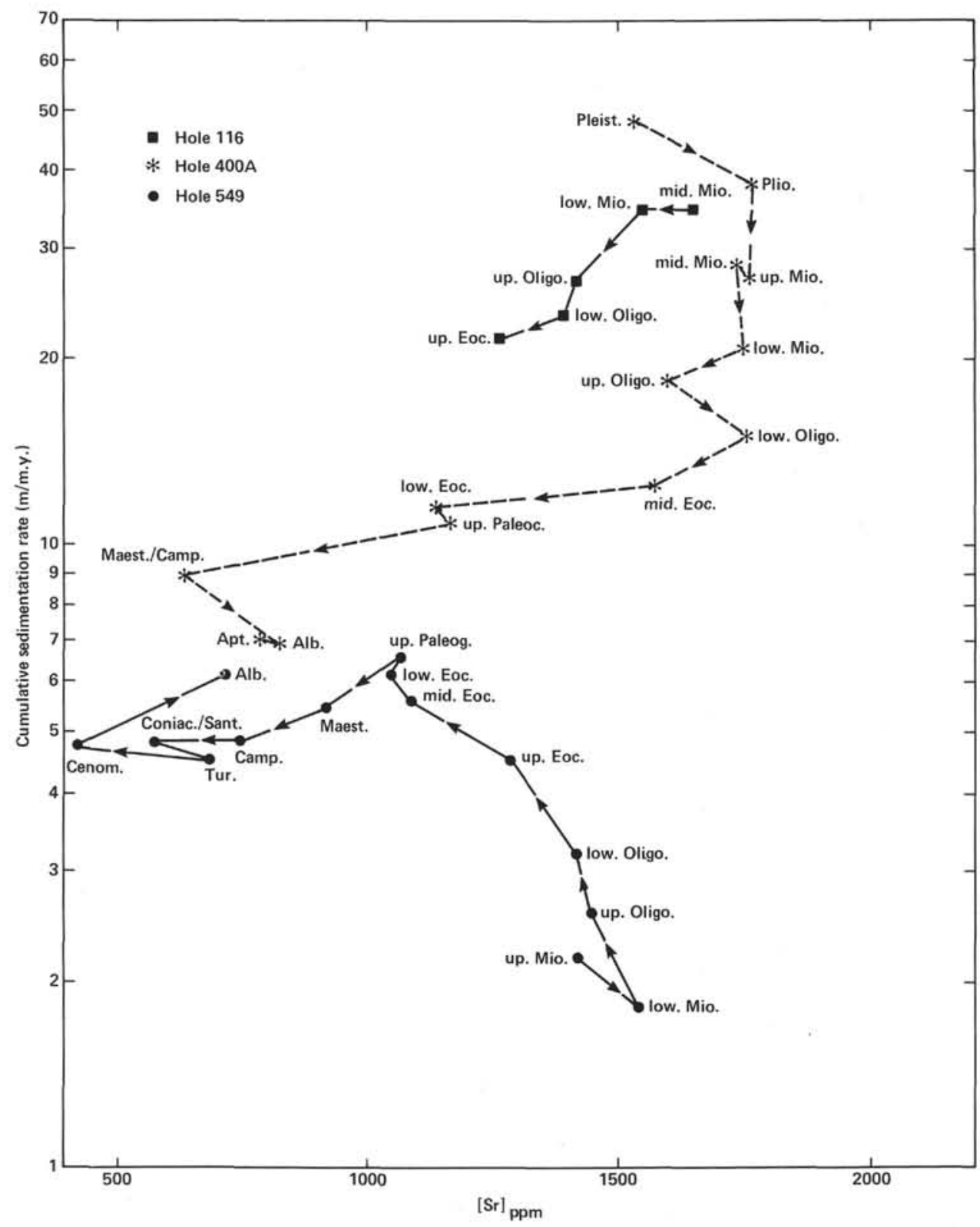

Figure 3. Relationship between the log of cumulative sedimentation rate and $\mathrm{Sr}$ concentration for Holes $116,400 \mathrm{~A}$, and 549 .

atively fast process and is thus sensitive to the sedimentation rate of each individual interval; in contrast, $\mathrm{Sr}$ diagenesis is a long-term phenomenon and is thus sensitive to the overall sedimentation rate at each site. This agrees with numerous previous observations (Lorens et al., 1977; Walls et al., 1977) of biogenic carbonates which have shown that a substantial amount of $\mathrm{Mg}$ is exchangeable and is thus very sensitive to dissolution phenomena and to early diagenesis.

We have noticed a break in the slope of $\mathrm{Sr}$ and $\mathrm{Mg}$ curves for the Paleocene interval, particularly for $\mathrm{Mg}$ at Site 549 (Fig. 4). This break may be the result of variations in sedimentation rates or of variations in seawater chemistry during Danian time. New results show that the $\mathrm{Sr} / \mathrm{Ca}$ and $\mathrm{Mg} / \mathrm{Ca}$ ratios of seawater changed during the Cenozoic (Graham et al., 1982) and Mesozoic (Renard, in press).

\section{Manganese}

The distribution curve for Hole 549 (Fig. 1) is not regular. Certain intervals, such as Albian (750-2000 ppm) and upper Paleocene to lower Miocene, are rich in $\mathrm{Mn}$ (1250-3750 ppm), and others, notably middle to Upper Cretaceous, are depleted in Mn (250-1250 ppm).

The sediments in Hole 550B, which lie on oceanic crust, shows systematically higher values than Hole 549 . However, this hole contains Mn-rich intervals (AlbianCenomanian; 100-4500 ppm) and Mn-poor intervals (Late Cretaceous-lower Paleocene, 750-2500 ppm).

It is now well established (Bostrom and Peterson, 1966; Klinkhammer, 1980) that the source of Mn in the ocean is mainly volcano-hydrothermal activity. In our previous publications (Renard, Létolle, et al., 1979; Rénard, Richebois, et al., 1979), we have shown the poten- 


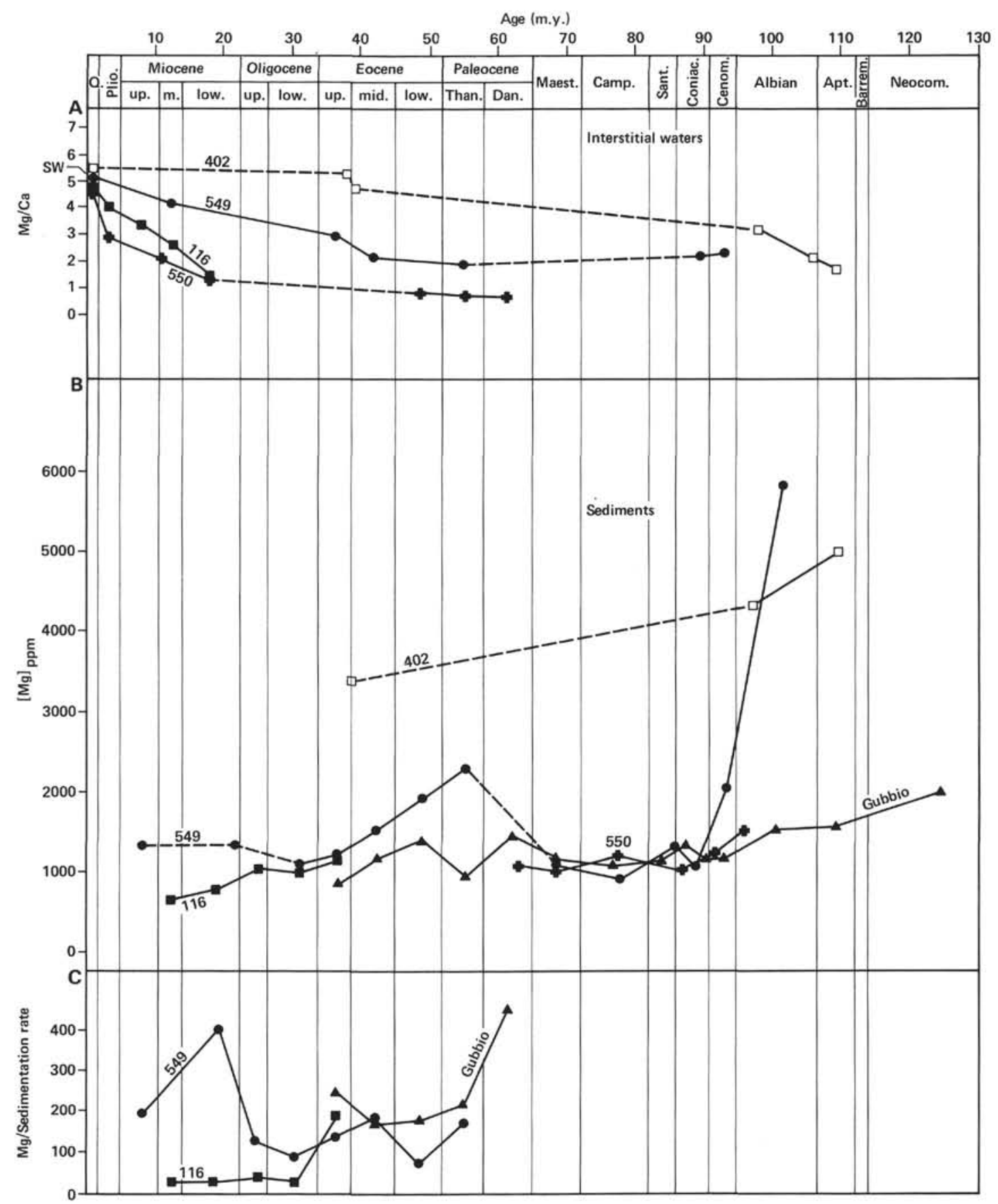

Figure 4. A. Evolution of $\mathrm{Mg} / \mathrm{Ca}$ in interstitial waters related to the age of sediments for the North Atlantic sites. B. Average $\mathrm{Mg}$ content of sediments related to their age for the same sites and for Gubbio section outcrop (Italy). C. Mg versus apparent sedimentation rate for the Tertiary sediments in the DSDP holes and for the Gubbio section outcrop. Dashed line as in Fig. 1.

tial use of $\mathrm{Mn}$ and $\mathrm{Fe}$ as time markers for the main seafloor spreading periods and as stratigraphic correlation tools (Odin et al., 1982).

The theoretical behavior of Mn during carbonate sedimentation is well known (Michard, 1969). Precipitation of $\mathrm{Mn}$ is controlled by two main phenomena:

1. Coprecipitation with calcite $\left(\mathrm{Ca}_{(1-x)} \mathrm{Mn}_{x}\right) \mathrm{CO}_{3}$ $(x \ll 1)$. Because of low Mn concentration in seawater and because $K_{\mathrm{Mn}}{ }^{\text {inorg }}=5.4 \pm 0.3$, these carbonates are impoverished in $\mathrm{Mn}(5 \mathrm{ppm}<\mathrm{Mn} \leq 55 \mathrm{ppm})$.
2. Precipitation of $\mathrm{MnO}_{2}$ when redox conditions of the environment are favorable. If Mn-poor biogenic calcites that fall on the seafloor stay long enough in the oxidizing layer of sediments, the precipitation of oxides (catalyzed by carbonates), such as ferric oxides and $\mathrm{MnO}_{2}$, leads to an increase in the Mn content of the sediments, but this $\mathrm{Mn}$ is not in the lattice of calcites.

The present $\mathrm{Mn}$ concentration values are compared with those from other North Atlantic DSDP holes, such as 116 (Rabussier, 1980), 390, 392 (Renard et al., 1978), 


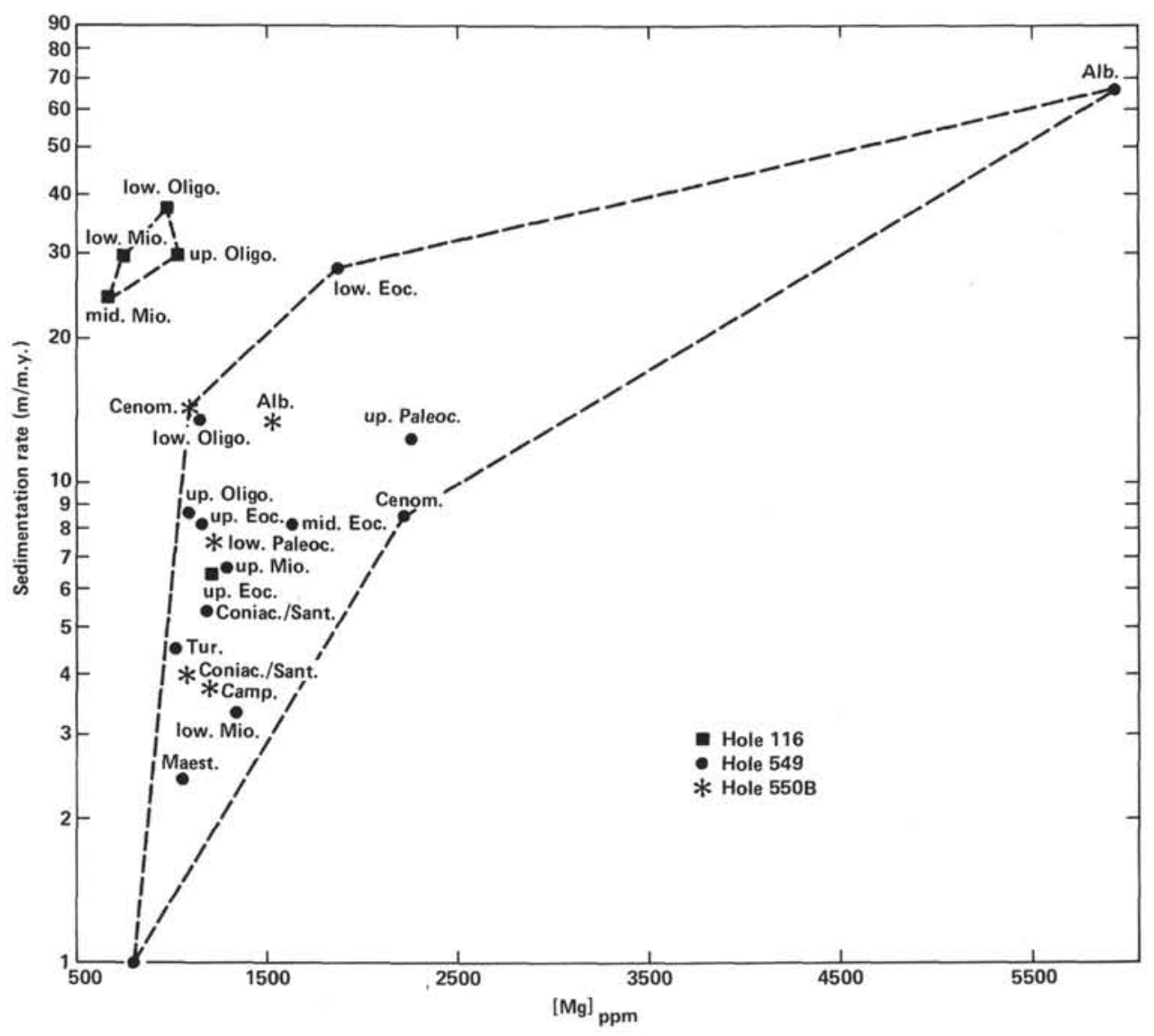

Figure 5. Relationship between the logarithm of sedimentation rates and $\mathrm{Mg}$ concentrations for Holes 116,549 , and $550 \mathrm{~B}$.

398 (Renard, Richebois et al., 1979), 400A, 401, and 402A (Renard, Létolle, et al., 1979; Andrianiazy, 1983). The sediments sampled in these holes represent a large variety of environments, in terms of depth, latitude, and type of substratum. We attempted to determine the role of these factors on $\mathrm{Fe}$ and Mn contents of pelagic carbonates.

\section{Mn Contents of North Atlantic Pelagic Carbonates: Evolution and Influence of Mid-Atlantic Ridge Activity}

The composite curves of Mn distribution show overall similarities among the sites (Fig. 7). We found Mnrich intervals (Albian and upper Paleocene to middle Eocene) and Mn-poor intervals (Upper Cretaceous and upper Oligocene to Holocene), already described in Figure 1 for Sites 549 and 550. There appears to be good correlation between Mn-rich periods and the main geodynamic events of the oceanic basin. The Albian was the main period of spreading in the Bay of Biscay (Williams, 1975) and the beginning of Mid-Atlantic Ridge activity in the Goban Spur area. Late Paleocene to middle Eocene time was the most active period in the opening history of the North Atlantic ocean. During this time, spreading began in the Reykjanes Ridge area, separating Rockall Plateau from Greenland (Roberts et al., 1979; Olivet et al., 1981).
There is a strong parallelism between the history of North Atlantic spreading (LePichon, 1968) and the evolution of Mn contents in pelagic sediments. During Aptian-Albian time, active rifting (beginning 120 m.y. ago) was followed by an episode of rapid spreading lasting about 30 m.y.; carbonate sediments of this time show very high Mn contents. This episode seems to have stopped during the mid-Cretaceous, and the Mn concentration decreased as well. During Late Cretaceous time, the spreading rate decreased notably and approached zero. Thus, we find very low Mn values in upper Maestrichtian and lower Paleocene sediments. During Paleocene time, spreading started again, extending northward to the Labrador Sea, Norway Sea, and Arctic Sea, correlating again with high $\mathrm{Mn}$ contents. Also during this period important volcanic activity occurred in northwestern Europe, the North Sea, and the North Atlantic Ocean, as confirmed by the presence of volcanic glass and tuff in the sediments (Harrison et al., 1979). From Oligocene to Miocene time, the spreading rate decreased again and probably stopped; this period corresponds to low-Mn contents. From late Miocene time, a new spreading cycle seems to have begun again but with a very slow rate. These numerous coincidences lead us to postulate that the variations in seafloor geodynamic activity correspond to variations of volcano-hydrothermal activity 


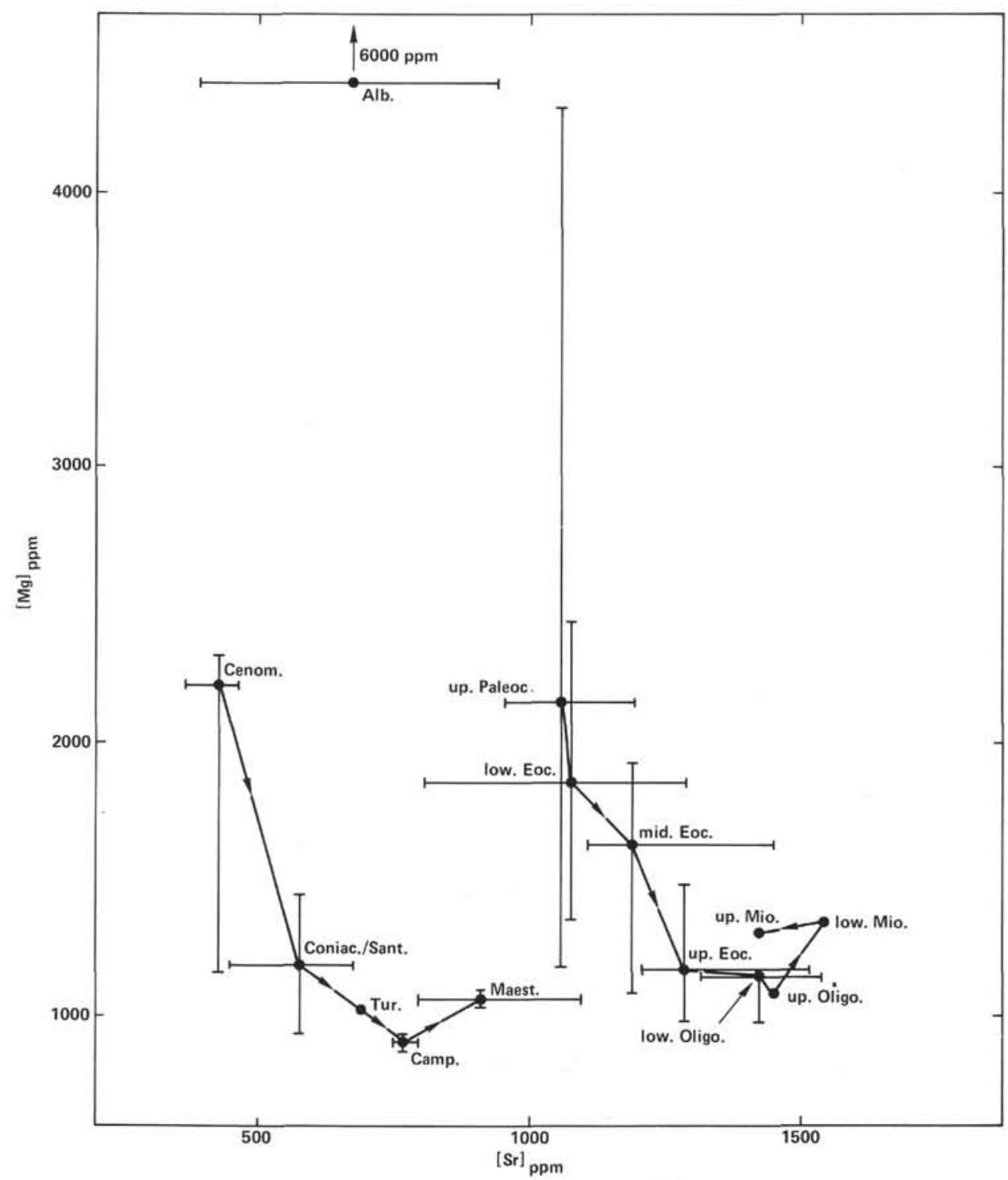

Figure 6. Relationship between average $\mathrm{Mg}$ and $\mathrm{Sr}$ concentrations in Hole 549 sediments.

on the ridges. Such variations are recorded by pelagic carbonates through fluctuations in Mn concentration.

\section{Influences of Paleodepth on Mn Concentrations: Role of Carbonate Dissolution}

Even if the relationship between mid-ocean ridge activity and Mn concentrations in pelagic carbonates seems well established, it is not as simple as our previous studies led us to believe. First of all, the differences in average Mn concentrations for fast-spreading versus slowspreading periods are too large to be explained solely by differences in ridge activity. Second, Mn concentrations in sediments of the same age are very different from one site to another. For instance, for middle and upper Eocene sediments, the average concentrations are 4500 ppm for Hole 400A, 3000 ppm for Hole 398, 1355 ppm for Hole 401, $900 \mathrm{ppm}$ for Hole 549, and $600 \mathrm{ppm}$ for Hole 402A.
These variations are not attributable to the distances from the ridge during Eocene time. For example, during the early Eocene, Holes $400 \mathrm{~A}$ and 398 were at approximately the same distance from the ridge (about 610 and $590 \mathrm{~km}$, respectively), whereas Hole 549 was closer (about $330 \mathrm{~km}$ ).

Moreover, there is no clear relationship between the Mn concentrations of a period and the corresponding sedimentation rate. Thus, the theoretical model based on the sedimentation rate being the sole factor controlling the Mn concentration is not applicable; however, as we shall see later, the sedimentation rate does play a role in $\mathrm{Mn}$ distribution.

Overall, there is a strong positive correlation between the log of the Mn content and the depth at which the sediments were deposited. Figure 8 shows for each site the evolution of the average Mn content related to the depth and, for each period, the correlation curves: $\log [\mathrm{Mn}]_{\mathrm{ppm}}=f$ (paleodepth) $)_{\mathrm{m}}$. The equations are 


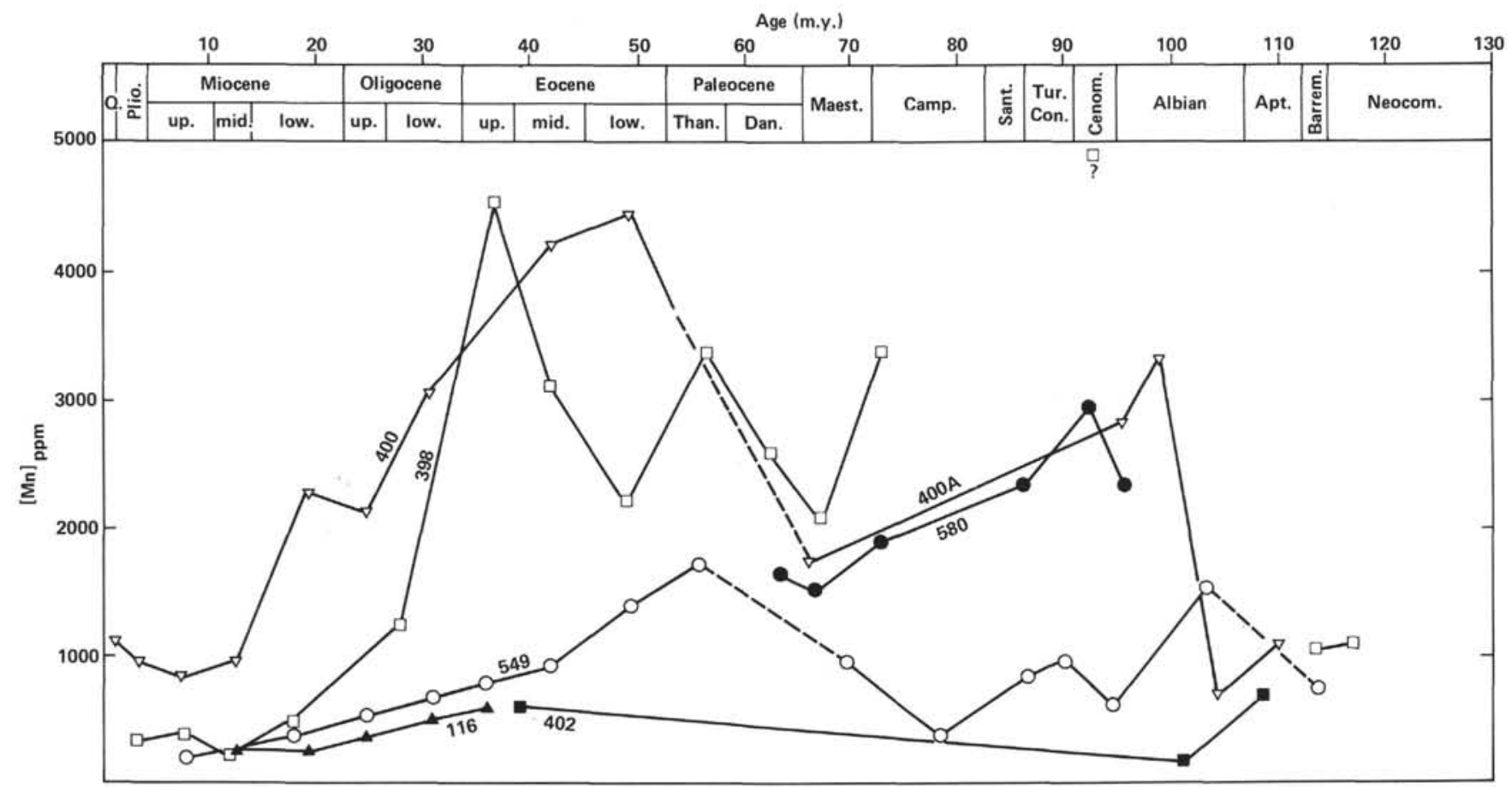

Figure 7. Evolution of average Mn concentrations versus age at the North Atlantic sites. Dashed line as in Fig. 1.

for Albian (correlation is calculated without including Hole 549, $r=0.986$ ):

$$
\log [\mathrm{Mn}]_{\mathrm{ppm}}=7.85 \times 10^{-4}(\text { depth })_{\mathrm{m}}+1.63
$$

for Maestrichtian $(r=0.855)$ :

$$
\log [\mathrm{Mn}]_{\mathrm{ppm}}=2.67 \times 10^{-4}(\text { depth })_{\mathrm{m}}+2.39
$$

for middle-upper Eocene (correlation is calculated without including Hole $116, r=0.905$ ):

$$
\log [\mathrm{Mn}]_{\mathrm{ppm}}=4.84 \times 10^{-4}(\mathrm{depth})_{\mathrm{m}}+1.73
$$

for upper Oligocene $(r=0.984)$ :

$$
\log [\mathrm{Mn}]_{\mathrm{ppm}}=2.19 \times 10^{-4}(\text { depth })_{\mathrm{m}}+2.31
$$

for upper Miocene $(r=0.826)$ :

$$
\log [\mathrm{Mn}]_{\mathrm{ppm}}=1.92 \times 10^{-4}(\text { depth })_{\mathrm{m}}+1.96
$$

The depth of deposition seems to be the determinative factor of Mn variability from one site to another. The ridge activity appears to be the factor which partially explains the variations between different periods. In fact, these influences are complementary, although one factor may be dominant at any one time. This happens, for example, at the onset of seafloor spreading. Albian sediments from Hole 549, although deposited in a shallow water environment $(-250 \mathrm{~m})$, are $\mathrm{Mn}$ rich because this site was close to the ridge. For this reason we do not take them into account for the correlation calculation. The same circumstances apparently existed during late Eocene at Site 116. The nature of the substratum, whether oceanic or continental, did not seem to play a role in the Mn distribution. The differences observed between Mn contents from Hole 549 (continental crust) and from Hole 550B (oceanic crust) are more a function of depth than of the nature of the substratum.

Correlation curves of the $\log$ of Mn contents versus depth (Fig. 8) are similar during supposed periods of low ridge activity (Maestrichtian, late Oligocene, and late Miocene) (slope lower than $3 \times 10^{-4}$ and the origin on the ordinate higher than 1.96 [90 ppm]) and during periods of very high ridge activity (Albian-middle Eocene) (slope higher than $4.5 \times 10^{-4}$ and the origin on the ordinate lower than $1.73[54 \mathrm{ppm}])$. This means that the greater the Mn production from the ridge, the more intense the influence of paleodepth on Mn concentrations.

This relationship leads us to consider the problem of the $\mathrm{CaCO}_{3}$ concentration. Because of the increasing dissolution of carbonates with depth, the dilution of $\mathrm{Mn}$ by calcareous biogenic sedimentation becomes less important with depth. In fact, numerous sites show a negative correlation between $\mathrm{Mn}$ and $\mathrm{CaCO}_{3}$ (Fig. 9). Sediments of Albian age do not conform to this correlation. Although depleted in $\mathrm{CaCO}_{3}$, sediments from Holes $549,550 \mathrm{~B}$, and $400 \mathrm{~A}$ are only moderately rich in $\mathrm{Mn}$. Similarly, samples of Miocene, Pliocene, and Pleistocene sediments from Hole $400 \mathrm{~A}$ are relatively low in Ca$\mathrm{CO}_{3}(45-65 \%)$ but have low $\mathrm{Mn}$ concentrations resulting from low production of Mn during these periods. In contrast, because of high Mn production during Cenomanian time, the sediments from Hole 398 are rich in $\mathrm{Mn}$ despite their similar $\mathrm{CaCO}_{3}$ contents $(55 \%)$.

The study of correlation coefficients shows that this negative relationship between $\mathrm{Mn}$ and $\mathrm{CaCO}_{3}$ is strong only for post-Upper Cretaceous sediments (Fig. 9). 


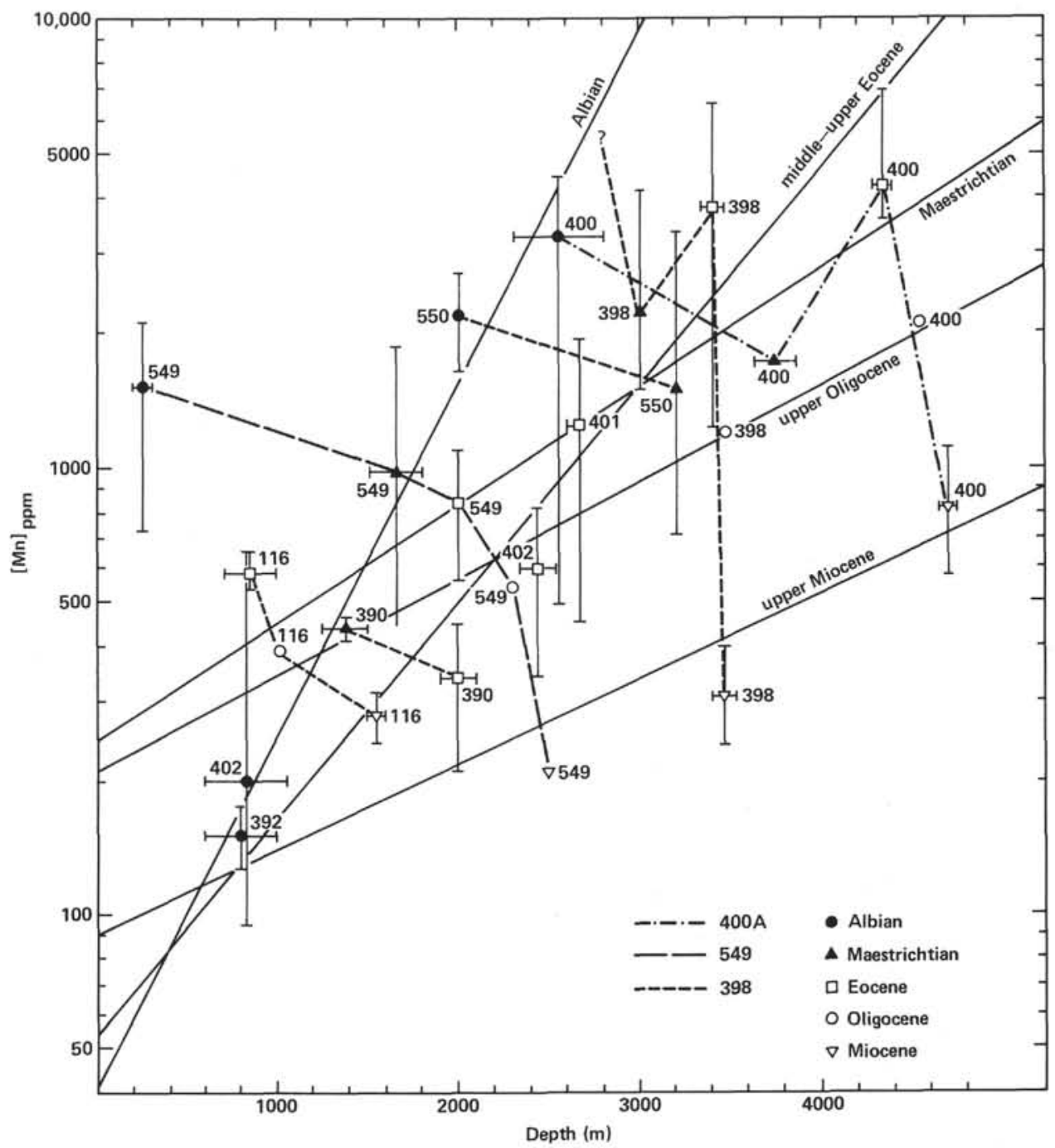

Figure 8. Relationship between the logarithm of Mn average contents and the depth during the Albian, Maestrichtian, Eocene, late Oligocene, and late Miocene. (Depths for Holes 549 and 550 are from site chapters, this volume.)

For the five test periods the calculation of correlation coefficient gives $r=-0.07$ for Albian, $r=-0.62$ for Maestrichtian, $r=-0.81$ for Eocene, $r=-0.99$ for Oligocene, and $r=-0.93$ for Miocene.

Therefore, for Eocene time, which is characterized by low $\mathrm{CaCO}_{3}$ content in all North Atlantic sites, is this Mn enrichment real or is it just a result of the low carbonate content? These two phenomena, in fact, are not completely independent: intense volcano-hydrothermal activity at the ridge could acidify the seawater and thus favor carbonate dissolution. (This could explain the steeper slope of the Eocene curve of $\log [\mathrm{Mn}]=f$ (depth) in Fig. 8.) To eliminate the problem of differential dilution of $\mathrm{Mn}$ by biogenic carbonates, we have recalculated the Mn concentrations with respect to $100 \%$ carbonate. We can define $[\mathrm{Mn}]^{100}$ as the concentration of Mn corrected by carbonate percentage:

$$
[\mathrm{Mn}]^{100}=\frac{[\mathrm{Mn}]_{\mathrm{ppm}} \times\left[\mathrm{CaCO}_{3}\right]_{\%}}{100}
$$

Using this recalculated $[\mathrm{Mn}]^{100}$ value, a new plot was made (Fig. 10). From this plot, we can make the following observations:

1. The differences in Mn concentrations for various sites are diminished, particularly for the post-Upper Cretaceous sediments.

2. The curves are more parallel and synchronous than before the treatment, particularly for Holes 400 and 398.

3. The recalculation has diminished the differences between high and low periods of concentrations, but it has not completely erased them. Thus, these differences are apparently not attributable solely to carbonate dilution. Furthermore, the Mn concentration curves do not follow the carbonate compensation depth (CCD) curve. Thus, the high- and low-Mn periods are real. In Cenomanian-Maestrichtian and lower Paleocene sediments, one can observe a continuous decrease of [Mn] ${ }^{100}$ (Sites 398 and 550). This is followed by an increase in the upper Paleocene and lower Eocene interval. From the mid- 

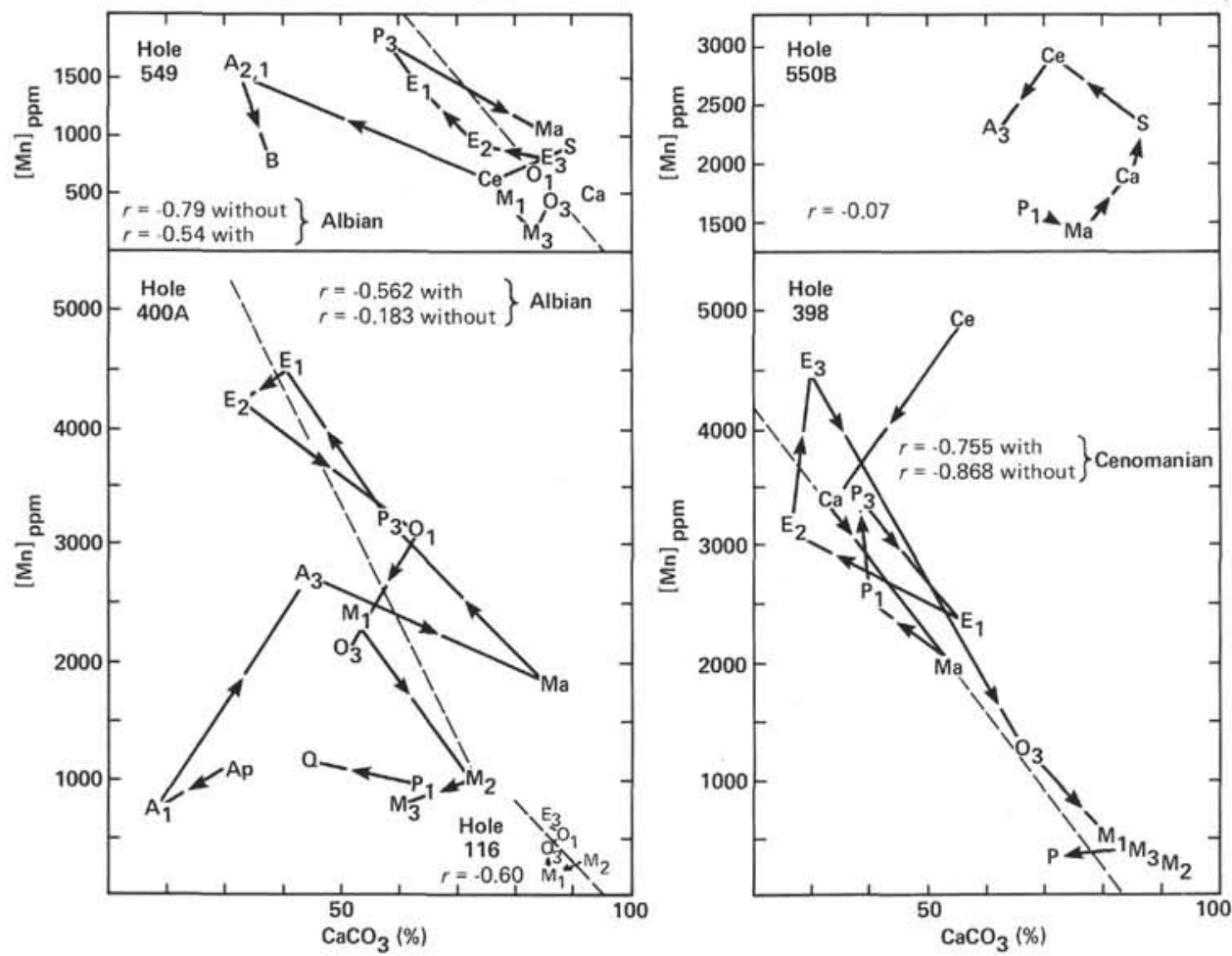

Figure 9. Relationship between average $\mathrm{CaCO}_{3}$ and $\mathrm{Mn}$ contents in sediments from Holes $116,398,400 \mathrm{~A}$, 549 , and 550B. Dashed line denotes correlation line. $\mathrm{Q}=$ Quaternary, $\mathrm{P}=$ Pleistocene, $\mathrm{M}=$ Miocene, $\mathrm{O}=$ Oligocene, $\mathrm{E}=$ Eocene, $\mathrm{P}_{1}$ or $\mathrm{P}_{3}=$ Paleocene, $\mathrm{Ma}=$ Maestrichtian, $\mathrm{Ca}=$ Campanian, $\mathrm{S}=$ Santonian, $\mathrm{Ce}=$ Cenomanian, $\mathrm{A}=$ Albian, $\mathrm{Ap}=$ Aptian, $\mathrm{B}=$ Barremian; $1=$ early, 2 = middle, $3=$ late.

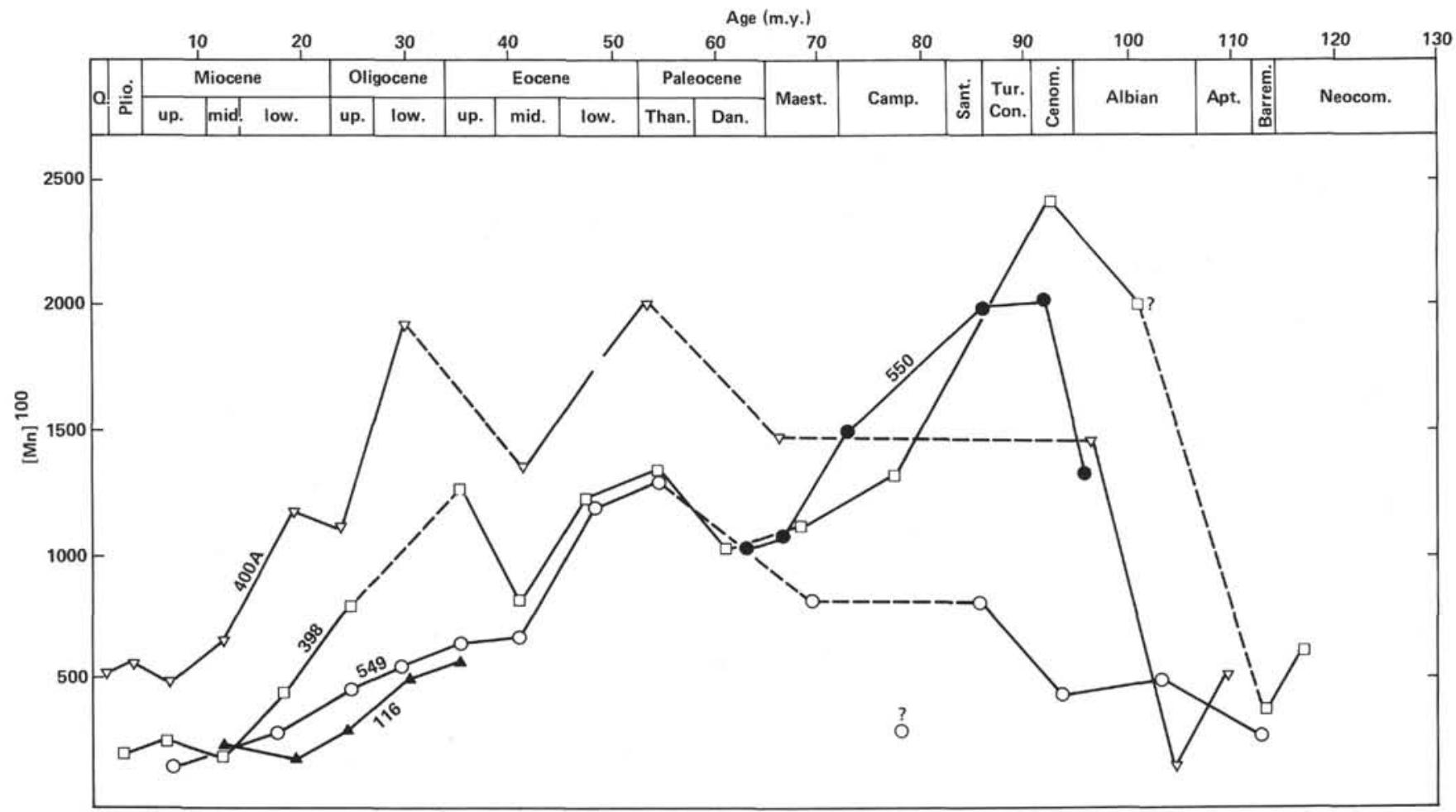

Figure 10. Evolution of $[\mathrm{Mn}]^{100}\left([\mathrm{Mn}]_{\mathrm{ppm}} \times \% \mathrm{CaCO}_{3} / 100\right)$ in Lower Cretaceous to Pleistocene pelagic carbonates from the North Atlantic sites. 
dle Eocene section upward, a general decrease can be seen (Sites 400, 398, and 549) but two cases should be distinguished (Fig. 10). At the northern sites (549-116), concentrations of $\mathrm{Mn}^{100}$ decrease regularly from the upper Eocene to the present, but the decrease becomes steeper in the Oligocene interval in Site 116. Also, at the midlatitude sites (400 and 398), one can see an increase of $\mathrm{Mn}^{100}$ values in the upper Eocene and lower Oligocene sections, followed by the same decrease as seen at northern sites. Because Sites 400 and 398 are the deepest ones, two explanations are possible. Either this was a local phenomenon (submarine volcanism?), or it was more widespread but oceanic conditions were such that only deep sites actually recorded it.

4. From Maestrichtian to the present, the $[\mathrm{Mn}]^{100}$ curve for Site 549 is similar to that for other sites, except for the mid-Cretaceous. We shall explain this observation later.

\section{Role of the Redox Conditions}

Is the relationship between $\log [\mathrm{Mn}]$ and depth only a result of the variation in $\mathrm{CaCO}_{3}$ ? This is not likely because the observed relationship between $[\mathrm{Mn}]^{100}$ and the depth confirm their correlation. A plot of $\log [\mathrm{Mn}]^{100}$ versus depth for the five test periods gives the following correlation curves (Fig. 11):

Albian (not including Hole 549, $r=0.972$; including Hole 549, $r=0.702)$ :

$$
\log [\mathrm{Mn}]_{\mathrm{ppm}}^{100}=7.95 \times 10^{-4}(\text { depth })_{\mathrm{m}}+1.32
$$

Maestrichtian $(r=0.873)$ :

$$
\log [\mathrm{Mn}]_{\mathrm{ppm}}^{100}=2.37 \times 10^{-4}(\text { depth })_{\mathrm{m}}+2.35
$$

middle-upper Eocene (not including Hole 116, $r=$ 0.797):

$$
\log [\mathrm{Mn}]_{\mathrm{ppm}}^{100}=3.05 \times 10^{-4}(\text { depth })_{\mathrm{m}}+1.94
$$

upper Oligocene $(r=0.993)$ :

$$
\log [\mathrm{Mn}]_{\mathrm{ppm}}^{100}=1.52 \times 10^{-4}(\text { depth })_{\mathrm{m}}+2.36
$$

upper Miocene $(r=0.75)$ :

$$
\log [\mathrm{Mn}]_{\mathrm{ppm}}^{100}=1.41 \times 10^{-4}(\text { depth })_{\mathrm{m}}+2.01
$$

By comparison of these curves with those in Figure 8, the following observations can be made:

1. The correction did not modify the curve for the Albian section (Figs. 8 and 11), which is different from the other curves.

2 . The correction has only slightly modified the curves for Maestrichtian, upper Oligocene, and upper Miocene sediments.

3. The modification is more important for the curve for the Eocene sediments, and its slope (although steep) is close to that for Maestrichtian, Oligocene, and Miocene sediments. Consequently, the Eocene interval shows a higher gradient of carbonate dissolution with depth than that of the Maestrichtian, Oligocene, and Miocene.

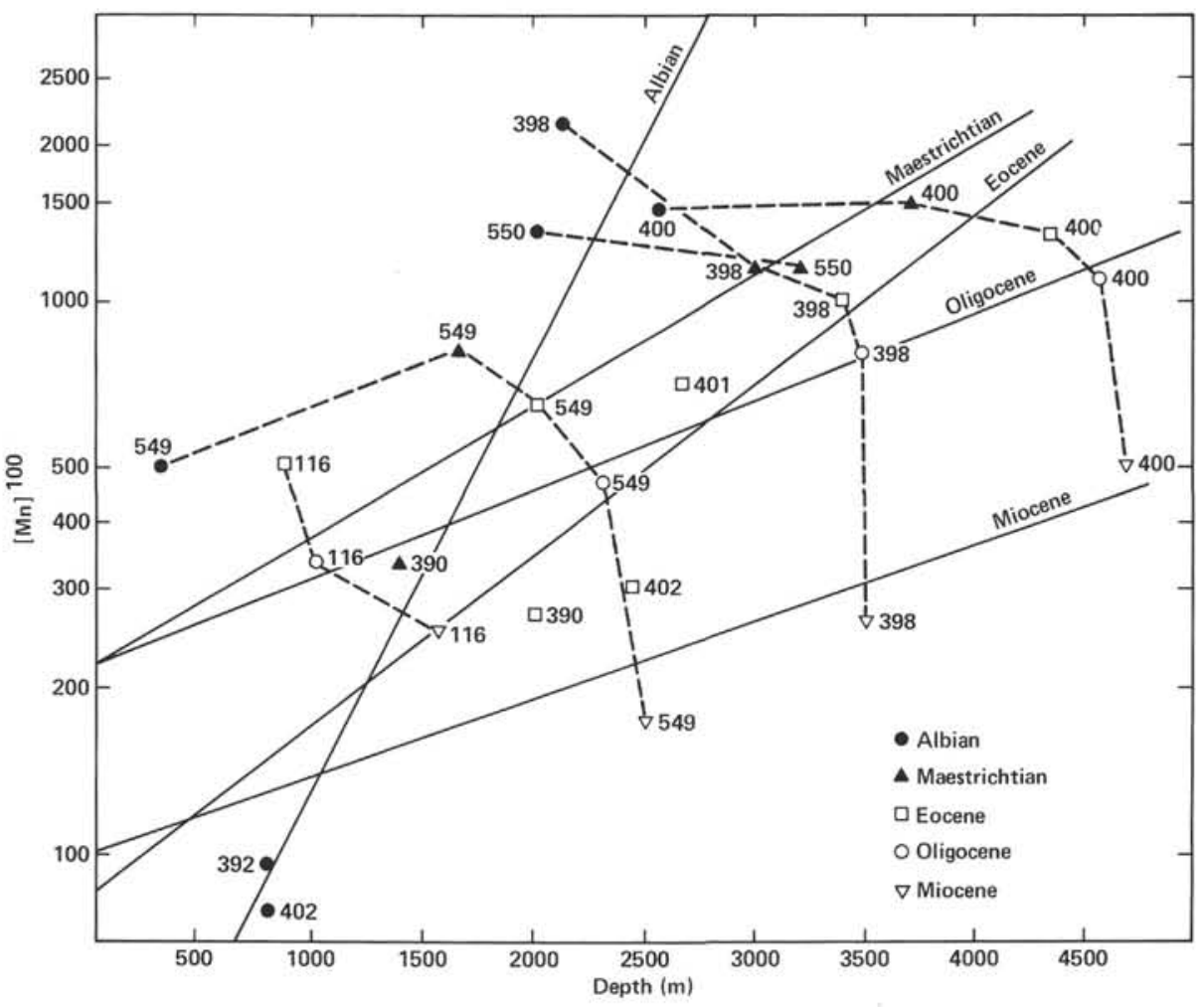

Figure 11. Relationship between the logarithm of $[\mathrm{Mn}]^{100}$ (defined in Fig. 10) and the depth of the site for the five test periods. 
Two other observations should be considered:

1. The post-Cretaceous sediments show a positive correlation between the slope of the curve of $\log [\mathrm{Mn}]^{100}=$ $f$ (depth) and the percentage of the hiatus (Doche, 1976) observed in North Atlantic holes drilled in sediments of the same age (Fig. 12). Although we do not have an exact compilation, it seems that the hiatus frequency for Albian time is very low and that the correlation does not hold. The existence of this correlation for the post-Cretaceous is important because the presence of a hiatus is partly the result of erosion by well-oxidized deep waters (Rabussier, 1980).

2. For any given age, an inverse exponential relationship exists between the slope of the curve of $\log [\mathrm{Mn}]^{100}$ $=f$ (depth) and the sedimentation rate (Fig. 13). This correlation does not hold for the Albian. The lower the sedimentation rate, the higher the Mn content of pelagic carbonates because the residence time of precipitated calcite in the oxidizing layer of sediments is correspondingly longer.

These two observations lead us to believe that redox conditions of the medium play a role in the influence of depth on variations of Mn concentration in sediments. As one moves downward from the oxygen minimum layer, oxygen increases (Kroopnick et al., 1972), and the presence of oxygenated bottom water makes it easier to precipitate $\mathrm{MnO}_{2}$. It seems that the late Paleocene and Eocene, which were periods when Mn production by the ridge was important, were also times when the environment was the most suitable for the precipitation of $\mathrm{Mn}$. During certain past geologic times, the oxygen minimum layer has gone through periods of expansion and contraction. Aptian to Albian time seems to have been a period with a particularly well-developed oxygen minimum layer (i.e., an anoxic period) (Fischer and Arthur, 1977). During this time, the seafloor of the North Atlantic began to spread and was very confined. During

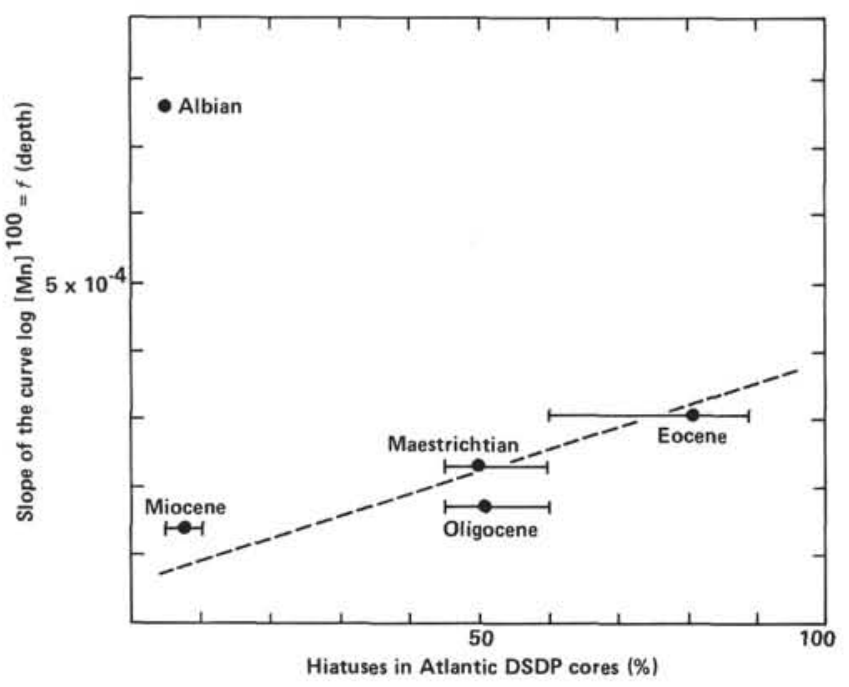

Figure 12. Relationship between the slope of the curve $\log [\mathrm{Mn}]^{100}=$ $f$ (depth) and the observed percentage of hiatuses for each test period. Dashed line denotes correlation line.

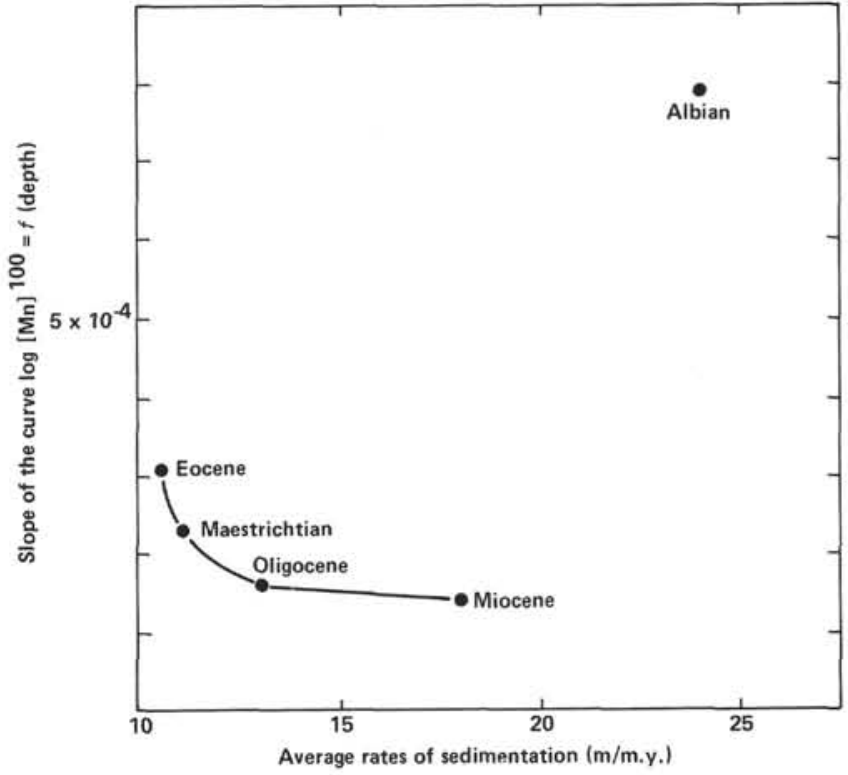

Figure 13. Relationship between the slope of the curve $\log [\mathrm{Mn}]^{100}=f$ (depth) and the average sedimentation rate for each test period.

these anoxic conditions, $\mathrm{MnO}_{2}$ could not easily precipjtate. This leads us to postulate that Mn production by the mid-ocean ridge was more important during Albian time than during Eocene time. This pattern would also explain the low-Mn content of sediments in Hole 549 because this site was shallow and close to the oxygen minimum layer in the past.

\section{Influence of the Distance from the Ridge}

There is a strong negative correlation between the log of the $[\mathrm{Mn}]^{100} /$ depth ratio and the distance from the ridge (Fig. 14). This means that after correction for the role of carbonate dilution and for depth, the distance from the ridge is apparently the controlling factor of Mn distribution in sediments. The equation $(r=0.70)$ is

$$
\left.\log \left([\mathrm{Mn}]^{100} / \text { depth }\right)=-1.003 \times 10^{-3} \text { (distance to ridge }\right)+3.06
$$

where the distance to the ridge is in $\mathrm{km}$.

In conclusion, $\mathrm{Mn}$ distribution in pelagic sediments appears to depend on three factors: (1) the activity of the ridge, (2) the depth, which controls carbonate dissolution and seafloor oxygenation, and (3) the distance from the ridge.

\section{Iron}

As in the case of Mn (Fig. 1), Fe distribution curves are not regular. In Hole 549, Albian and mid-Cretaceous sediments are Fe rich $(1250-6500 \mathrm{ppm})$, whereas Upper Cretaceous and lower Paleocene sediments are impoverished in $\mathrm{Fe}$ (10-50 ppm). Upper Paleocene to upper Eocene carbonates are moderately enriched $(100-$ $380 \mathrm{ppm}$ ). From lower Oligocene to present sediments, the concentrations are low (10-50 ppm). Comparison of this distribution to that of Mn shows that their variations correlate. However, Albian is more enriched in $\mathrm{Fe}$ 


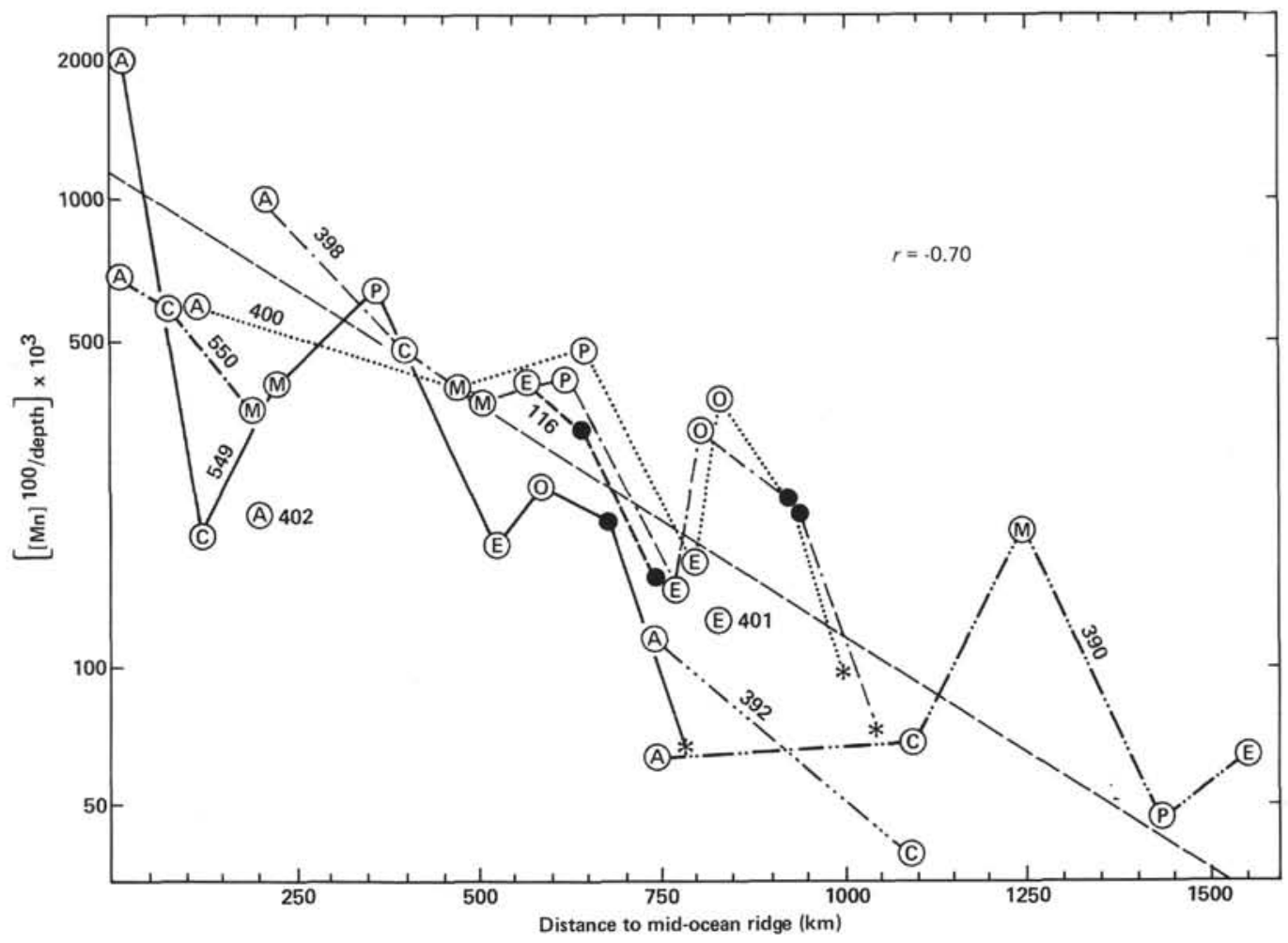

Figure 14. Relationship between the log of average $[\mathrm{Mn}]^{100}$ content versus depth and distance from the ancient midocean ridge for each site. Even dashes denote correlation line. $\mathrm{A}=$ Albian; $\mathrm{C}=$ Cenomanian; $\mathbf{M}=$ Maestrichtian; $\mathrm{P}=$ Paleocene; $\mathrm{E}=$ Eocene; $\mathrm{O}=$ Oligocene; $\bullet=$ Miocene; ${ }^{*}=$ Quaternary.

than Mn. In contrast, upper Paleocene and Eocene sediments are more enriched in $\mathrm{Mn}$ than in Fe.

As already demonstrated for $\mathrm{Mn}, \mathrm{Fe}$ concentrations are systematically higher in Hole 550 than in Hole 549 (500-2050 ppm for the upper Albian and mid-Cretaceous sediments).

The curves of average Fe concentrations for several North Atlantic sites (Fig. 15) seem to be more complex than those for Mn, but again a general Albian-Cenomanian enrichment can be observed at all sites. Whereas all sites show high-Mn concentrations, only Site 116 (close to the ridge) shows an enrichment in Fe. This distribution is a result of the difference in the chemical behavior of $\mathrm{Mn}$ and $\mathrm{Fe}$. Iron oxides are less soluble than oxides of $\mathrm{Mn}$, and therefore $\mathrm{Fe}$ is quickly trapped in sediments. Fe enrichment is more a function of times of seafloor spreading and proximity to mid-ocean ridge areas than is $\mathrm{Mn}$. During spreading periods, $\mathrm{Fe}$ and $\mathrm{Mn}$ could have simultaneously precipitated if the site had been close to the ridge, but if it had been farther from the ridge, only Mn would have precipitated. For lower Miocene upward through the present sediments (at least for Biscay Bay Holes 398 and 400A), one can observe an increase in the Fe content of the sediments. This is probably the result of a detrital supply of particulate or soluble $\mathrm{Fe}$ or both.

The relationship of $\mathrm{Fe}$ concentration to the percentage of carbonates and to depth seems more complicated than that for $\mathrm{Mn}$ and requires more elaborate study.

\section{CONCLUSIONS}

The comparison of $\mathrm{Sr}, \mathrm{Mg}, \mathrm{Fe}$, and $\mathrm{Mn}$ distributions in Holes 549 and 550B with those of the other Atlantic sites leads us to make the following conclusion.

1. The negative $\mathrm{Sr} / \mathrm{Mg}$ correlation, related to carbonate diagenesis, has been confirmed for at least the Tertiary sediments. The neoformed calcites are enriched in $\mathrm{Mg}$ and depleted in $\mathrm{Sr}$ by exchange with interstitial waters.

2. It is not clear what factors play a dominant role during carbonate diagenetic transformations. It would seem that $\mathrm{Mg}$ diagenesis is a relatively rapid phenomenon, sensitive to the individual sedimentation rates of each time period, whereas $\mathrm{Sr}$ diagenesis is more likely a longer term phenomenon, sensitive to the overall sedimentation rate at the site and particularly to the residence time of sediments in a given diagenetic environment. Consequently, Sr loss from pelagic carbonates could serve as a rough method of dating individual sediment layers.

3. The data from Hole 549 show a break in $\mathrm{Sr}$ and $\mathrm{Mg}$ curves between Tertiary and Cretaceous time. This may be the result of variations in the seawater chemistry, but the influence of a change in the sedimentation rate should also be considered.

4. The results enable us to specify the influence of different factors (e.g., volcano-hydrothermal activity of the mid-ocean ridge, depth of sedimentation, $\mathrm{CaCO}_{3}$ dis- 


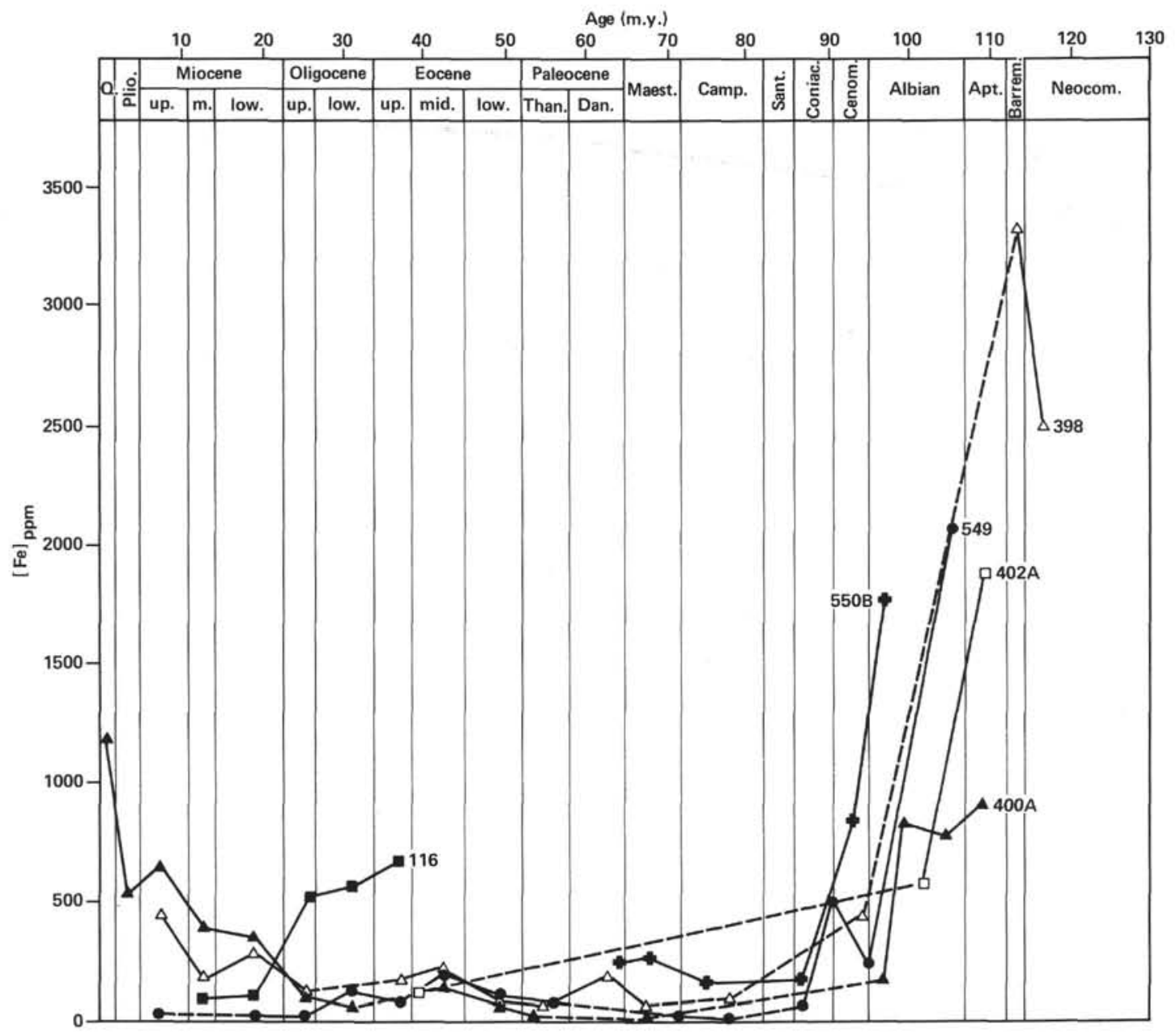

Figure 15. Average Fe contents of sediments in the North Atlantic sites. Dashed line as in Fig. 1.

solution, redox state of the medium, and distance from the ridge) on the $\mathrm{Fe} / \mathrm{Mn}$ distribution in pelagic sediments and to conclude that the nature of the substratum, whether continental or oceanic, does not play an important role in the trace element content of the overlying sediments.

\section{ACKNOWLEDGMENTS}

The authors gratefully acknowledge P. C. de Graciansky for discussions and for supplying samples and J. Gieskes and J. Veizer for their helpful reviews of this paper. Thanks are extended to A. Altman and J. P. Peypouquet for their help during sampling at Lamont Doherty Geological Observatory, and to J. Gieskes for communication concerning interstitial water chemistry at Sites 540-550. Many thanks are also due to M. Gilbert Richebois and Mrs. Eva Truptil for their laboratory assistance and to Mrs. Anne Demond for typing the manuscript.

Funds for this research were provided by B.R.G.M. and by C.N.R.S. through ATP GGO.

\section{REFERENCES}

Andrianiazy, A., 1983. Influences des conditions de sédimentation et de diagenèse sur le comportement geochimique des éléments traces $(\mathrm{Sr}, \mathrm{Mg}, \mathrm{Fe}, \mathrm{Mn}$ ) des carbonates pélagiques de Sites 543 et 550 (D.S.D.P. Leg 80). Applications à l'Albien des Sites 369A, 402A, 418B, du domaine vocontien et du bassin de Paris [Thèse 3ème cycle]. Mem. 83-50, Univ. Pierre et Marie Curie, Paris.
Baker, P. A., Gieskes, J. M., and Elderfield, H., 1982. Diagenesis of carbonates in deep-sea sediments-evidence from $\mathrm{Sr} / \mathrm{Ca}$ ratios and interstitial dissolved $\mathrm{Sr}^{2+}$ data. J. Sediment. Petrol., 52:71-82.

Boström, K., and Peterson, M. N. A., 1966. Precipitates from hydrothermal exhalations on the East Pacific Rise. Econ. Geol., 61: 1258-1265.

Curry, D., and Odin, G. S., 1982. Dating of the Paleogene. In Odin, G. S. (Ed.), Numerical Dating in Stratigraphy: New York (Wiley).

Doche, J. L., 1976. Les hiatus de sédimentation dans les forages du project JOIDES-DSDP. Mem. Int., Soc. Nat. Pet. Aquitaine.

Elderfield H., Gieskes, J. M., Baker, P. A., Oldfield, R. K., Hawkesworth, C. J., and Miller, R., $1982 .{ }^{87} \mathrm{Sr} /{ }^{86} \mathrm{Sr}$ and ${ }^{18} \mathrm{O} /{ }^{16} \mathrm{O}$ ratios, interstitial water chemistry and diagenesis in deep-sea carbonate sediments of the Ontong Java Plateau. Geochim. Cosmochim. Ac$t a, 46: 2259-2268$.

Fischer, A. G., and Arthur, M. A., 1977. Secular variations in the pelagic realm in deep water carbonate environments. Spec. Publ. Soc. Econ. Paleontol. Mineral., 25:19-50.

Gieskes, J. M., 1976. Interstitial water studies, Leg 33. In Schlanger, S. O., Jackson, E. D., et al., Init. Repts. DSDP, 33: Washington (U.S. Govt. Printing Office), 563-570.

Graham, D. W., Bender, M. L., Williams, D. F., and Keigwin, L. D., 1982. Strontium-calcium ratio in Cenozoic planktonic foraminifera. Geochim. Cosmochim. Acta, 46:1281-1292.

Harrison, R. K., Knox, R. W. O., Morton, A. C., Merriman, R. J., and Wheatley, C. W., 1979. Petrography and mineralogy of volcanogenic sediments from DSDP Leg 48, South-West Rockall Plateau, Sites 403 and 404, In Montadert, L., Roberts, D. G., et al., Init. Repts. DSDP, 48: Washington (U.S. Govt. Printing Office), 771-786. 
Katz, A., Sass, E., Starinsky, A., and Holland, H. D., 1972. Strontium behavior in the aragonite-calcite transformation: An experimental study at $40-98^{\circ} \mathrm{C}$. Geochim. Cosmochim. Acta, 36:481-496.

Kennedy, W. J., and Odin, G. S., 1982. The Jurassic and Cretaceous time scale in 1981. In Odin, G. S. (Ed.), Numerical Dating in Stratigraphy: New York (Wiley).

Kinsman, D. J. J., 1969. Interpretation of $\mathrm{Sr}^{2+}$ concentrations in carbonate minerals and rocks. J. Sediment. Petrol., 39:486-508.

Klinkhammer, G. P., 1980. Observations of the distribution of manganese over the East Pacific Rise. Chem. Geol., 29:211-226.

Kroopnick, P., Weiss, R. F., and Craig, H., 1972. Total $\mathrm{CO}_{2},{ }^{13} \mathrm{C}$ and dissolved oxygen- ${ }^{18} \mathrm{O}$ at Geosecs II in the North Atlantic. Earth Planet. Sci. Lett., 16:103-110.

LePichon, X., 1968. Sea floor spreading and continental drift. J. Geophys. Res., 73:3661-3697.

Lorens, R. B., Williams, D. F., and Bender, M. L., 1977. The early nonstructural chemical diagenesis of foraminiferal calcite. J. Sediment. Petrol., 47:1602-1609.

Manheim, F. T., and Sayles, F. L., 1971. Interstitial water studies on small core samples, Deep Sea Drilling Project, Leg 8. In Tracey, J. I., Jr., Sutton, G. H., et al., Init. Repts. DSDP, 8: Washington (U.S. Govt. Printing Office), 857-869.

Michard, G., 1969. Contribution à l'étude du comportemant du manganèse dans la sédimentation [Ph.D. dissert.]. Université de Paris.

Odin, G. S., Renard, M., and Vergnaud Grazzini, C., 1982. Geochemical events as a mean of correlation. In Odin, G. S. (Ed.), Numerical Dating in Stratigraphy: New York (Wiley), pp. 37-71.

Rabussier, D., 1980. Variations de composition isotopique de l'oxygène et du carbone en milieu marin et coupures stratigraphiques du Cénozoïque [Thèse 3ème cycle]. Université Pierre et Marie Curie, Paris.

Renard, M., in press. Géochimie des carbonates pélagiques: mise en évidence des fluctuations de la composition chimique des eaux océaniques depuis $140 \mathrm{Ma}$. Essai de chimiostratigraphie [Thèse d'État]. Univ. Pierre et Marie Curie, Paris.

Renard, M., and Blanc P., 1971. Mise au point d'un protocole expérimental pour le dosage d'éléments en traces $(\mathrm{V}, \mathrm{Cr}, \mathrm{Mn}, \mathrm{Ni}, \mathrm{Sr}$, and Mo) par absorption atomique. C. R. Acad. Sci., 272:2285-2288. 1972. Influence des conditions de mise en solution (choix de l'acide, température et durée d'attaque) dans le dosage des élé- ments en traces des roches carbonatées. C. R. Acad. Sci., 274: 632-635.

Renard, M., Delacotte, O., and Létolle, R., 1982. Le strontium et les isotopes stables dans les carbonates totaux de quelques sites de l'Atlantique et de la Téthys. Bull. Soc. Geol. Fr., 7th Series, 24: 519-534.

Renard, M., Létolle, R., and Bourbon, M., 1978. Some trace elements in the carbonate samples recovered from Holes 390,390A, 391C, and 392A of Leg 44. In Benson, W. E., Sheridan, R. E., et al., Init. Repts. DSDP, 44: Washington (U.S. Govt. Printing Office), 557-566.

Renard, M., Létolle, R., and Richebois, G., 1979. Some trace elements and their relation to oxygen and carbon isotopes in the carbonate samples recovered from Hole 400A of DSDP. Leg 48, In Montadert, L., Roberts, D. G., et al., Init. Repts. DSDP, 48: Washington (U.S. Govt. Printing Office), 727-740.

Renard, M., Richebois, G., and Létolle, R., 1979. Strontium, manganese, and iron contents, and oxygen isotopes in the carbonate fractions recovered from Hole 398C, Leg 47B. In Ryan, W. B. F., Sibuet, J. C, et al., Init. Repts. DSDP, 47, Pt. 2, Washington (U.S. Govt. Printing Office), 497-506.

1983. Trace element and stable isotope geochemistry of $\mathrm{Pa}$ leocene to Coniacian carbonate samples from Hole 516F, comparison with North Atlantic and Tethys sites. Init. Repts. DSDP, 72: Washington (U.S. Govt. Printing Office), 399-420.

Roberts, D. G., Montadert, L., and Searle, R. C., 1979. The western Rockall Plateau: stratigraphy and structural evolution. In Montadert, L., Roberts, A. G., et al., Init. Repts. DSDP, 48: Washington (U.S. Govt. Printing Office), 1061-1088.

Walls, R. A., Ragland, P. C., and Crisp, E. L., 1977. Experimental and natural early diagenetic mobility of $\mathrm{Sr}$ and $\mathrm{Mg}$ in biogenic carbonates. Geochim. Cosmochim. Acta, 41:1731-1737.

Williams, C. A., 1975. Sea-floor spreading in the Bay of Biscay and its relationship to the North Atlantic. Earth Planet Sci. Lett., 24: 440-456.

Date of Initial Receipt: April 25, 1983

Date of Acceptance: November 8, 1983 